\title{
Chemical preparations, crystal data for monophosphates and condensed phosphates associated to strontium and IR studies of their anions
}

\author{
Rachida Oubouaza ${ }^{1}$, Hamza Marouani ${ }^{1}$, Soufiane Zerraf ${ }^{1}$, Mustafa Belhabra ${ }^{1}$, Ali Ouasri ${ }^{2}$, \\ MalikaTridane $^{1,3}$, Said Belaaouad ${ }^{1}$ \\ ${ }^{1}$ Laboratory of Chemistry-Physics of Materials, Faculty of Sciences Ben M'Sik B. P. 7955, Hassan II \\ University of Casablanca, Casablanca, Morocco. \\ ${ }^{2}$ Regional Center for Education and Training Trades, Madinat Al Irfane, Souissi,BP 6210 Rabat, Morocco. \\ ${ }^{3}$ Regional Center for Education and Training Trades, Bd Bir Anzarane Casablanca. Morocco.
}

\begin{abstract}
Chemical preparations and main crystallographic data are reported for the Monophosphates and the condensed phosphates associated to strontium. These compounds constituting an important part of phosphate chemistry have been subject to many studies and applications in many fields of research on materials and industry. The subject of this paper is to collect unit-cell parameters of these compounds to build a database of the different formulas which are known until now, to have an idea about their preparations and also about characterization by infrared vibration spectrometry for anions, $\mathrm{PO}_{3}{ }^{-}$in $\alpha-\mathrm{Sr}\left(\mathrm{PO}_{3}\right)_{2}, \mathrm{PO}_{4}{ }^{3-}$ in $\gamma-\mathrm{SrHPO}_{4}, \mathrm{P}_{2} \mathrm{O}_{7}{ }^{4-}$ in $\mathrm{Sr}_{2} \mathrm{P}_{2} \mathrm{O}_{7}, \mathrm{P}_{3} \mathrm{O}_{9}{ }^{3-}$ in $\mathrm{SrKP}_{3} \mathrm{O}_{9} \cdot 3 \mathrm{H}_{2} \mathrm{O}, \mathrm{P}_{4} \mathrm{O}_{12}{ }^{4-}$ in $\mathrm{SrK}_{2} \mathrm{P}_{4} \mathrm{O}_{12}$, $\mathrm{P}_{6} \mathrm{O}_{18}{ }^{6-}$ in $\mathrm{Sr}_{2}\left(\mathrm{NH}_{4}\right)_{2} \mathrm{P}_{6} \mathrm{O}_{18} .7 \mathrm{H}_{2} \mathrm{O}$ and $\mathrm{P}_{3} \mathrm{O}_{10}{ }^{5-}$ in $\mathrm{Sr}_{3} \mathrm{P}_{3} \mathrm{O}_{10} \mathrm{Cl}$.
\end{abstract}

Key words : Chemical preparation, monophosphates, strontium, infrared vibration spectrometry-ray diffraction.

\section{INTRODUCTION}

Before we start reviewing and discussing the chemical preparation and crystallographic data of phosphate we first try to explain what we commonly call a phosphate. A general and rather abstract definition can be given by saying that phosphates are salts of both the monophosphoric acid $\mathrm{H}_{3} \mathrm{PO}_{4}$ and its various condensed or polymeric forms. The corresponding anions have varied geometries, but one common feature: they are all built up by pentavalent phosphorus atoms surrounded by more or less distorted tetrahedra made of four oxygen atoms. Monophosphate known as orthophosphates is the only phosphates known to be naturally occurring because of the hydrolysis of condensed phosphates. The condensed phosphoric anion in which P-O-P bonds exist is a condensed phosphoric anion. The condensed phosphates and monophosphates associated to strontium, the subject of this paper, contained in the important condensed phosphates and monophosphates that have been the subject of research and apply in the industry. The present work assembled the majority of the phases prepared for condensed phosphates and monophosphates associated to strontium to get ideas about their preparation, their crystallographic data, and their vibrational characteristics [1].

\section{Monophosphates $\mathrm{PO}_{4}{ }^{3-}$}

\subsection{Synthesis protocols}

$\alpha-\mathrm{SrHPO}_{4}$

It is easily obtained by dissolving $2.1 \mathrm{~g}$ of $\operatorname{Sr}\left(\mathrm{NO}_{3}\right)_{2}$ and $1.4 \mathrm{~g}$ of $\mathrm{NH}_{4} \mathrm{H}_{2} \mathrm{PO}_{4}$ in $200 \mathrm{~cm}^{3}$ of water. After three days, after evaporation at room temperature, crystals appear of $\mathrm{SrHPO}_{4}$, polyhedral and colourless form, stable at room temperature and are very soluble in water [2].

$\mathrm{\beta}_{-\mathrm{SrHPO}}$

The $\beta-\mathrm{SrHPO}_{4}$ was prepared via a controlled hydrothermal method. $\mathrm{Sr}\left(\mathrm{NO}_{3}\right)_{2}$ and $\left(\mathrm{NH}_{4}\right)_{2} \mathrm{HPO}_{4}$ were dissolved in $50 \mathrm{ml}$ deionized water with a molar ratio of 0.03:0.0001:0.02 under mechanical stirring for $2 \mathrm{~h}$. Then the mixed solution was transferred into a $100 \mathrm{ml}$ Teflon bottle. The bottle was held in a stainless steel autoclave and kept at $180^{\circ} \mathrm{C}$ for $12 \mathrm{~h}$. Finally, the obtained white $\mathrm{SrHPO}_{4}$ powders were filtered, washed for three times with deionized water and twice with ethanol and then dried in a vacuum oven at $60^{\circ} \mathrm{C}$ for $12 \mathrm{~h}$ [3]. $\gamma$-SrHPO

They were prepared from a mixture comprising $\mathrm{Li}_{2} \mathrm{CO}_{3}$ (599.5\%), $\mathrm{SrCO}_{3}(598 \%), \mathrm{H}_{3} \mathrm{PO}_{4}(85 \%)$ and distilled water in molar ratio $\mathrm{Li} / \mathrm{Sr} / \mathrm{P} / \mathrm{H}_{2} \mathrm{O}=1 / 1 / 3 / 190$. The reactants were introduced in a Teflon-lined Parr hydrothermal bomb, with a fill factor of approximately 50\%. The bomb was heated at $180^{\circ} \mathrm{C}$ under auto-geneous pressure for 6 days, and then slowly cooled to room temperature over 24 hours. The bomb contents were recovered by vacuum filtration and drying in 
Rachida Oubouaza et al., International Journal of Emerging Trends in Engineering Research, 8(9), September 2020, 6587 - 6598

air. Repeated attempts to prepare $\gamma$-SrHPO 4 hydrothermally from $\mathrm{SrCO}_{3}, \quad \mathrm{H}_{3} \mathrm{PO}_{4}$, and $\mathrm{H}_{2} \mathrm{O} \quad\left(\mathrm{Sr} / \mathrm{P} / \mathrm{H}_{2} \mathrm{O}=1 / 1.9 / 60\right.$, $\mathrm{T}=140^{\circ} \mathrm{C}, 2$ days) allowed the authors to obtain a white microcrystalline powder for this phase [4].

\section{$\mathrm{Sr}_{1.9} \mathrm{Cu}_{4.1}\left(\mathrm{PO}_{4}\right)_{4}, \mathrm{Sr}_{3} \mathrm{Cu}_{3}\left(\mathrm{PO}_{4}\right)_{4}, \mathrm{Sr}_{2} \mathrm{Cu}\left(\mathrm{PO}_{4}\right)_{2}$ and $\mathrm{Sr}_{9.1} \mathrm{Cu}_{1.4}\left(\mathrm{PO}_{4}\right)_{7}$}

Samples in the $\mathrm{Sr}_{3-x} \mathrm{Cu}_{x}\left(\mathrm{PO}_{4}\right)_{2}$ system were synthesized from stoichiometric mixtures of $\mathrm{CuO}$ (99.9\%), $\mathrm{SrCO}_{3}(99.999 \%)$, and $\mathrm{NH}_{4} \mathrm{H}_{2} \mathrm{PO}_{4}(99.999 \%)$ by the solid state method. Stoichiometric mixtures were heated very slow up to $600^{\circ} \mathrm{C}$ and then annealed at $900^{\circ} \mathrm{C}(120 \mathrm{~h}$, ground every $30 \mathrm{~h})$ under air in alumina crucibles. The samples with $x=0,0.289,0.4$, $0.414,0.429,1,1.05,1.25,1.5,1.75,2,2.05,2.075,2.125$, 2.5 , and 3 were obtained. After annealing, the samples were quenched at room temperature. For synthesis of solid solutions $\mathrm{Sr}_{9.1-x} \mathrm{Ca}_{x} \mathrm{Cu}_{1.4}\left(\mathrm{PO}_{4}\right)_{7}(0 \leq x \leq 9.1), \mathrm{Sr}_{2-x} \mathrm{Ba}_{x} \mathrm{Cu}\left(\mathrm{PO}_{4}\right)_{2}(0 \leq$ $x \leq 2)$ and $\mathrm{Sr}_{3-x} \mathrm{Ba}_{x} \mathrm{Cu}_{3}\left(\mathrm{PO}_{4}\right)_{4}(0 \leq x \leq 1.5)$, we used also $\mathrm{CaCO}_{3}$ $(99.0 \%)$ and $\mathrm{BaCO}_{3}(99.0 \%)$. Solid solutions $\mathrm{Sr}_{9.1-}$ ${ }_{x} \mathrm{Ca}_{x} \mathrm{Cu}_{1.4}\left(\mathrm{PO}_{4}\right)_{7}(0 \leq x \leq 9.1)$ were synthesized at $900-920^{\circ} \mathrm{C}$ followed by quenching in air. Solid solutions $\mathrm{Sr}_{2-x} \mathrm{Ba}_{x} \mathrm{Cu}\left(\mathrm{PO}_{4}\right)_{2}(0 \leq x \leq 2)$ and $\mathrm{Sr}_{3-x} \mathrm{Ba}_{x} \mathrm{Cu}_{3}\left(\mathrm{PO}_{4}\right)_{4}(0 \leq x \leq 1.5)$ were synthesized at $840^{\circ} \mathrm{C}$ followed by quenching in air.

Make some remarks about the synthesis of the three new compounds in the $\mathrm{Sr}_{3-x} \mathrm{Cu}_{x}\left(\mathrm{PO}_{4}\right)_{2}$ system with $x=0.4,1$, and 2.05. The single-phased samples $\mathrm{Sr}_{1.9} \mathrm{Cu}_{4.1}\left(\mathrm{PO}_{4}\right)_{4}(x=2.05)$ and $\mathrm{Sr}_{2} \mathrm{Cu}\left(\mathrm{PO}_{4}\right)_{2} \quad(x=1)$ could be obtained at $900^{\circ} \mathrm{C}$. Annealing of the sample $\mathrm{Sr}_{1.9} \mathrm{Cu}_{4.1}\left(\mathrm{PO}_{4}\right)_{4}$ at $950^{\circ} \mathrm{C}$ resulted in the appearance of a liquid phase. This specimen contained I$\mathrm{Sr}_{3} \mathrm{Cu}_{3}\left(\mathrm{PO}_{4}\right)_{4}, \mathrm{Cu}_{3}\left(\mathrm{PO}_{4}\right)_{2}$, and traces of unidentified phases. A long treatment of $\mathrm{Sr}_{1.9} \mathrm{Cu}_{4.1}\left(\mathrm{PO}_{4}\right)_{4}$ at $950^{\circ} \mathrm{C}$ resulted in the growth of $\mathrm{I}_{-} \mathrm{Sr}_{3} \mathrm{Cu}_{3}\left(\mathrm{PO}_{4}\right)_{4}$ single crystals.

Annealing of the blue specimen $\mathrm{Sr}_{2} \mathrm{Cu}\left(\mathrm{PO}_{4}\right)_{2}$ at $1020^{\circ} \mathrm{C}$ resulted in a green powder, which consisted of an unidentified phase (phase I with six strongest lines: $d=2.657$, $3.121,2.800,3.098,2.784$, and $2.702 \AA$ ) and traces of $\mathrm{Sr}_{9.1} \mathrm{Cu}_{1.4}\left(\mathrm{PO}_{4}\right)_{7}$ and $\mathrm{I}-\mathrm{Sr}_{3} \mathrm{Cu}_{3}\left(\mathrm{PO}_{4}\right)_{4}$. Traces of phase I, $\mathrm{Sr}_{9.1} \mathrm{Cu}_{1.4}\left(\mathrm{PO}_{4}\right)_{7}$, and $\mathrm{I}-\mathrm{Sr}_{3} \mathrm{Cu}_{3}\left(\mathrm{PO}_{4}\right)_{4}$ appeared when $\mathrm{Sr}_{2} \mathrm{Cu}\left(\mathrm{PO}_{4}\right)_{2}$ was annealed at $920^{\circ} \mathrm{C}$.

Our attempts to synthesize at $900^{\circ} \mathrm{C}$ the compound $\mathrm{Sr}_{9.1} \mathrm{Cu}_{1.4}\left(\mathrm{PO}_{4}\right)_{7} \quad(x=0.4)$ from $\mathrm{SrCO}_{3}(99.999 \%)$ were not successful, even when platinum crucibles and quenching in liquid nitrogen were used.

The specimens in these cases were blue and consisted of three phases, $\mathrm{Sr}_{3}\left(\mathrm{PO}_{4}\right)_{2}, \mathrm{Sr}_{9.1} \mathrm{Cu}_{1.4}\left(\mathrm{PO}_{4}\right)_{7}$ and $\mathrm{Sr}_{2} \mathrm{Cu}\left(\mathrm{PO}_{4}\right)_{2}$, in comparable amounts. When the specimen $\mathrm{Sr}_{9.1} \mathrm{Cu}_{1.4}\left(\mathrm{PO}_{4}\right)_{7}$ was cooled in a furnace, it was light-gray and also consisted of the three phases. The compound $\mathrm{Sr}_{9.1} \mathrm{Cu}_{1.4}\left(\mathrm{PO}_{4}\right)_{7}$ (with traces of $\mathrm{Sr}_{3}\left(\mathrm{PO}_{4}\right)_{2}$ ) could be obtained by quenching from $1000^{\circ} \mathrm{C}$ into air in a platinum crucible. The single-phased sample $\mathrm{Sr}_{9.1} \mathrm{Cu}_{1.4}\left(\mathrm{PO}_{4}\right)_{7}(x=0.4)$ in the amount of $0.1 \mathrm{~g}$ was obtained in a corundum crucible by quenching from $9003 \mathrm{C}$ into air when we used $\mathrm{SrCO}_{3}$ (98.0\%), $\mathrm{CuO}$ (99.9\%), and $\mathrm{NH}_{4} \mathrm{H}_{2} \mathrm{PO}_{4}(99.999 \%)$ in synthesis. It seems that impurities can stabilize the $\mathrm{Sr}_{9.1} \mathrm{Cu}_{1.4}\left(\mathrm{PO}_{4}\right)_{7}$ phase [5].

\section{$\mathrm{SrCu}_{2}\left(\mathrm{PO}_{4}\right)_{2}$}

$\mathrm{SrCu}_{2}\left(\mathrm{PO}_{4}\right)_{2}$ was synthesized by the solid-state method from stoichiometric mixtures of $\mathrm{Sr}_{3}\left(\mathrm{PO}_{4}\right)_{2}$ and $\mathrm{Cu}_{3}\left(\mathrm{PO}_{4}\right)_{2}$ at $1153 \mathrm{~K}$ in a Pt crucible for $200 \mathrm{~h}$ with five intermediate grindings. The green-blue product was cooled in a furnace. $\mathrm{SrCu}_{2}\left(\mathrm{PO}_{4}\right)_{2}$ contained $\mathrm{Sr}_{3} \mathrm{Cu}_{3}\left(\mathrm{PO}_{4}\right)_{4}(1.2 \%)$ impurities. The mass fraction of the impurity in the sample was calculated from the scale factors refined in the Rietveld analysis described below. Single-phased $\mathrm{Cu}_{3}\left(\mathrm{PO}_{4}\right)_{2}$ and $\mathrm{Sr}_{3}\left(\mathrm{PO}_{4}\right)_{2}$ were prepared from mixtures of $\mathrm{CuO}(99.99 \%), \mathrm{NH}_{4} \mathrm{H}_{2} \mathrm{PO}_{4}$ (99.999\%), and $\mathrm{SrCO}_{3}(99.999 \%)$ by the solid-state method. The mixtures were heated under air while the temperature was very slowly increased from room temperature (RT) to $873 \mathrm{~K}$; then, they were reground and allowed to react at $1153 \mathrm{~K}$ for $\mathrm{Cu}_{3}\left(\mathrm{PO}_{4}\right)_{2}$, and $1273 \mathrm{~K}$ for $\mathrm{Sr}_{3}\left(\mathrm{PO}_{4}\right)_{2}$ for $120 \mathrm{~h}$ with four intermediate grindings [6].

\section{$\mathrm{KSrPO}_{4}$}

$\mathrm{KSrPO}_{4}: \mathrm{Dy}^{3+}(\mathrm{x}=0.03,0.04,0.05,0.06,0.07$, and 0.08) phosphors were synthesized using a solid-state reaction method. Highly pure $\mathrm{K}_{2} \mathrm{CO}_{3}, \mathrm{SrCO}_{3},\left(\mathrm{NH}_{4}\right)_{2} \mathrm{HPO}_{4}(99.9 \%)$, and $\mathrm{Dy}_{2} \mathrm{O}_{3}$ (99.99\%) obtained from Sinopharm Chemical Reagent, Co. Ltd., Shanghai China, were used as the starting materials. Stoichiometric amounts of $\mathrm{O}_{2} \mathrm{CO}_{3}$, $\mathrm{SrCO}_{3},\left(\mathrm{NH}_{4}\right)_{2} \mathrm{HPO}_{4}$ (99.9\%), and $\mathrm{Dy}_{2} \mathrm{O}_{3}$ (99.99\%) were mixed thoroughly in alcohol by ball milling using an agate mortar. Additional 5\% $\mathrm{K}_{2} \mathrm{CO}_{3}$ was used to compensate the losses due to evaporation during the synthesis. They were sintered at $1150^{\circ} \mathrm{C}$ for $6 \mathrm{~h}$ in air, and then, the samples were ground into powder for characterization [7].

\section{$\mathrm{KSrFe}_{2}\left(\mathrm{PO}_{4}\right)_{3}$}

Single crystals of $\mathrm{KSrFe}_{2}\left(\mathrm{PO}_{4}\right)_{3}$ were grown in a flux of potassium dimolybdate $\mathrm{K}_{2} \mathrm{Mo}_{2} \mathrm{O}_{7}$ with molar ratio of product: flux $=2: 1$ starting from $2.043 \mathrm{~g}$ of $\mathrm{KNO}_{3}, 1.506 \mathrm{~g}$ of $\mathrm{SrCO}_{3}, 8.203 \mathrm{~g}$ of $\mathrm{Fe}\left(\mathrm{NO}_{3}\right)_{3} .9 \mathrm{H}_{2} \mathrm{O}, 4.002 \mathrm{~g}$ of $\left(\mathrm{NH}_{4}\right)_{2} \mathrm{HPO}_{4}$ and $1.454 \mathrm{~g}$ of $\mathrm{MoO}_{3}$. These reactants were mixed in nitric acid and the resulting solution was evaporated to dryness by heating at $353 \mathrm{~K}$. The obtained dry residue was ground in an agate mortar and then heated for $24 \mathrm{~h}$ at $673 \mathrm{~K}$ in order to remove the decomposition products: $\mathrm{NH}_{3}, \mathrm{CO}_{2}$.

The process was then followed by a further heating for 12hat $873 \mathrm{~K}$ with intermediate grinding. After being reground, the product was melted for $1 \mathrm{~h}$ at $1373 \mathrm{~K}$, and then slowly cooled at a rate of $10 \mathrm{~K} . \mathrm{h}^{-1}$ to $673 \mathrm{~K}$, then at a rate of $50 \mathrm{~K} \cdot \mathrm{h}^{-1}$ to room temperature. The crystals obtained by washing the final product with warm water, in order to dissolve the flux, are essentially composed by yellowish and irregularly shaped crystals. Their qualitative microprobe analysis indicated the exclusive presence of $\mathrm{K}, \mathrm{Sr}, \mathrm{Fe}$ and $\mathrm{P}$ in an atomic ratio approximating 1:1:2:3, in accordance with the $\mathrm{KSrFe}_{2}\left(\mathrm{PO}_{4}\right)_{3}$ composition After its structure determination, the title compound was prepared in the powder form by the conventional solid state reaction. After an initial treatment similar to that undertaken for the synthesis of the single crystals until $873 \mathrm{~K}$, the sample was subjected to final calcinations at $1273 \mathrm{~K}$ for $48 \mathrm{~h}$ with 
Rachida Oubouaza et al., International Journal of Emerging Trends in Engineering Research, 8(9), September 2020,6587 - 6598

intermittent grinding. Yellowish powder was obtained by quenching in air [8].

\section{$\mathrm{SrCo}_{2}\left(\mathrm{PO}_{4}\right)_{2}$}

A stoichiometric mixture of $\mathrm{SrCO}_{3}, \mathrm{CoCO}_{3}$, and $\left(\mathrm{NH}_{4}\right)_{2} \mathrm{HPO}_{4}$ of high purity. (>>99\%) was heated to $1173 \mathrm{~K}$ to effect decarbonation, then heated to fusion $(1473 \mathrm{~K})$ in a platinum crucible followed by slow cooling $\left(10^{\circ} \mathrm{C} / \mathrm{h}\right)$. The product contained two types of crystals distinguishable by their color: rose and blue. Those of blue color correspond to the powder of composition $\mathrm{SrCo}_{2}\left(\mathrm{PO}_{4}\right)_{2}$ [9].

\section{$\beta-\mathrm{SrCo}_{2}\left(\mathrm{PO}_{4}\right)_{2}$}

All reagents were used as received without further purification except $\alpha-\mathrm{Co}_{2} \mathrm{P}_{2} \mathrm{O}_{7}$ which was synthesized by solid state reaction. Single crystal of $\beta-\mathrm{SrCo}_{2}\left(\mathrm{PO}_{4}\right)_{2}$ was prepared through a facile hydrothermal synthesis route. A mixture of $\alpha-\mathrm{Co}_{2} \mathrm{P}_{2} \mathrm{O}_{7}(0.0584 \mathrm{~g}, 0.2 \mathrm{mmol}), \operatorname{Sr}\left(\mathrm{NO}_{3}\right)_{2}$ $(0.0846 \mathrm{~g}, 0.4 \mathrm{mmol})$ and $5 \mathrm{~mL} \mathrm{H}_{2} \mathrm{O}$ was stirred for $10 \mathrm{~min}$ in air. The obtained mixture was then transferred into a $28 \mathrm{~mL}$ Teflon-lined autoclave and heated at $230^{\circ} \mathrm{C}$ in an oven for $120 \mathrm{~h}$. The autoclave was cooled down to room temperature at a rate of $0.1{ }^{\circ} \mathrm{C} / \mathrm{min}$, and purple rhombus-shaped crystals of $\mathrm{b}-\mathrm{SrCo}_{2}\left(\mathrm{PO}_{4}\right)_{2}$ were isolated, washed with distilled water and dried in air at $60^{\circ} \mathrm{C}[10]$.

\section{$\mathrm{Sr}_{5}\left(\mathrm{PO}_{4}\right)_{3}\left(\mathrm{CuO}_{2}\right)_{1 / 3}$}

$\mathrm{SrCO}_{3}, \mathrm{NH}_{4} \mathrm{H}_{2} \mathrm{PO}_{4}$ and $\mathrm{CuO}(99,99 \%)$ thoroughly ground and mixed in a 5.05:3: $\mathrm{x}$ molar ratio $(\mathrm{x} \leq 1)$ were heated stepwise at400, 600 and $850{ }^{\circ} \mathrm{C}$ for $32 \mathrm{~h}$ with intermediate regrindings. The powders were pressed in pellets, annealed in air at $1100{ }^{\circ} \mathrm{C}$ for 24 hours and air quenched . The samples had blue-violet color that became lighter for low copper content. XRD patterns of specimens with $0.1<\mathrm{x} 0.8$ corresponded to practically pure apatite phase $(0.6 \% \max$ peak intensity of impurities) [11].

\section{* Crystallographic data}

Table 1: Main Crystallographic data for the monophosphates associated to strontium

\begin{tabular}{|l|c|c|c|l|c|}
\hline \multicolumn{1}{|c|}{ Formula } & $\begin{array}{c}\mathrm{a}(\AA) \\
\alpha^{\circ}\end{array}$ & $\begin{array}{c}\mathrm{b}(\AA) \\
\beta^{\circ}\end{array}$ & $\begin{array}{c}\mathrm{c}(\AA) \\
\gamma^{\circ}\end{array}$ & $\begin{array}{c}\text { Space } \\
\text { Group }\end{array}$ & $\mathrm{Z}$ \\
\hline$\alpha-\mathrm{SrHPO}_{4}$ & 7.184 & 6.790 & 7.256 & $\mathrm{P}-1$ & 4 \\
& 94.7 & 104.9 & 88.7 & & \\
\hline$\gamma-\mathrm{SrHPO}_{4}$ & 8.131 & 9.258 & 18.084 & $\mathrm{Pbca}$ & 16 \\
\hline \multirow{2}{*}{$\mathrm{Sr}_{5}\left(\mathrm{PO}_{4}\right)_{3}\left(\mathrm{CuO}_{2}\right)_{1 / 3}$} & 9.7815 & 9.7815 & 7.3018 & $\mathrm{P} 6_{3} / \mathrm{m}$ & 2 \\
\hline $\mathrm{SrCo}_{2}\left(\mathrm{PO}_{4}\right)_{2}$ & 5.014 & 8.639 & 9.691 & $\mathrm{P}-1$ & 2 \\
\hline $\mathrm{BaCu}_{2}\left(\mathrm{PO}_{4}\right)_{2}$ & 118.04 & 75.09 & 86.90 & & \\
& 9.226 & 9.271 & 10.516 & $\mathrm{P}-1$ & 4 \\
& 106.76 & 101.69 & 115.70 & & \\
\hline $\mathrm{KSrPO}_{4}$ & 7.35 & 5.56 & 9.64 & Pnma & 4 \\
\hline
\end{tabular}

\begin{tabular}{|l|c|c|r|l|c|}
\hline $\mathrm{SrCu}_{2}\left(\mathrm{PO}_{4}\right)_{2}$ & 7.94217 & 15.36918 & 10.37036 & $\mathrm{Pccn}$ & 8 \\
\hline$\beta-\mathrm{SrCo}_{2}\left(\mathrm{PO}_{4}\right)_{2}$ & 5.503 & 6.703 & 9.238 & $\mathrm{P}-1$ & 2 \\
& 110.235 & 101.15 & 98.29 & & \\
\hline $\mathrm{Sr} \mathrm{Cu}_{\left(\mathrm{PO}_{4}\right)_{2}}$ & 11.5155 & 5.07543 & 6.57487 & $\mathrm{C} 2 / \mathrm{m}$ & 2 \\
& & 106.3563 & & & \\
\hline $\mathrm{Sr}_{3} \mathrm{Cu}_{3}\left(\mathrm{PO}_{4}\right)_{4}$ & 9.2010 & 4.94104 & 17.8998 & $\mathrm{P} 21 / \mathrm{c}$ & 2 \\
& & 122.8952 & & & \\
\hline $\mathrm{Sr}_{2} \mathrm{Cu}_{3}\left(\mathrm{PO}_{4}\right)_{4}$ & 10.6119 & 10.6119 & 19.7045 & $\mathrm{R}-3_{1} \mathrm{~m}$ & 3 \\
\hline $\mathrm{KSrFe}_{2}\left(\mathrm{PO}_{4}\right)_{3}$ & 9.809 & 9.809 & 9.809 & $\mathrm{P} 2{ }_{1} 3$ & 4 \\
& & & & & \\
\hline
\end{tabular}

* Characterization of $\mathrm{PO}_{4}{ }^{3-}$ in $\gamma-\mathrm{SrHPO}_{4}$ by IR vibration spectrometry

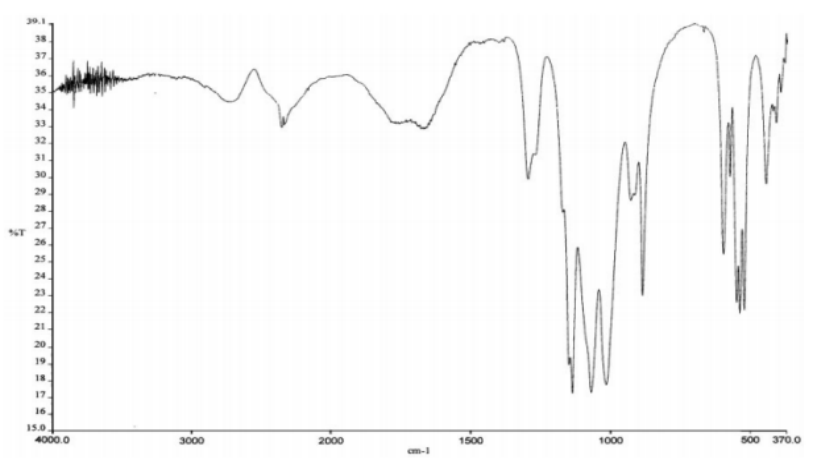

Figure 1: Infrared spectrum of $\gamma-\mathrm{SrHPO}_{4}$ recorded at room temperature between 370 and $4000 \mathrm{~cm}^{-1}$.

Table 2: Frequencies $\left(\mathrm{cm}^{-1}\right)$ of IR absorption bands for $\gamma$ $\mathrm{SrHPO}_{4}$

\begin{tabular}{|c|c|}
\hline Frequencies $\left(\mathrm{cm}^{-1}\right)$ & Vibrations \\
\hline 1298 & SP-O-H \\
\hline $1170,1146,1137$ & asymmetric $\left(v_{3}\right)$ \\
\hline 887 & P-O $(\mathrm{H})$ \\
\hline $1070,1016,929,915$ & symmetric $\left(v_{1}\right)$ \\
\hline $600-520$ & antisymmetric $\left(v_{4}\right)$ \\
\hline $450-370$ & symmetric $\left(v_{2}\right)$ \\
\hline
\end{tabular}

The IR spectrum of $\gamma-\mathrm{SrHPO}_{4}$ is reported in Fig.1. Previous workers [11,12] have found that the vibrational bands of inorganic phosphates are generally not very sensitive to the cations in the structure, which tend just to shift the band frequencies slightly rather than to create new bands. Thus, the IR spectrum is dominated by the $\mathrm{HPO}_{4}{ }^{2-}$ modes.

The 2800-1700 $\mathrm{cm}^{-1}$ range corresponds to the $\mathrm{OH}$ modes of $\mathrm{HPO}_{4}{ }^{2-}$ groups characterized by three broad bands of $\mathrm{ABC}$ type. Similar bands have been observed in strong hydrogen bonded crystals, such as $\mathrm{CaBa}\left(\mathrm{HPO}_{4}\right)_{2}$ and $\mathrm{PbHPO}_{4}$. The presence of bands in the region $1400-1200 \mathrm{~cm}^{-1}$ is characteristic of hydrogen monophosphate groups. 
They are assigned to $\delta \mathrm{P}-\mathrm{O}-\mathrm{H}$ in plane bending modes, two bands 1298 and $1267 \mathrm{~cm}^{-1}$ are observed for these modes. In the range 1200-800 $\mathrm{cm}^{-1}$ appear the $\mathrm{PO}_{4}{ }^{3-}$ stretching modes: the high-frequency bands $\left(1170,1146,1137 \mathrm{~cm}^{-1}\right)$ are assigned to the asymmetric $\left(v_{3}\right)$ mode, whereas the symmetric stretching mode of $\mathrm{P}-\mathrm{O}(\mathrm{H})$ is observed for the low-frequency $887 \mathrm{~cm}^{-1}$.

The remaining bands $\left(1070,1016,929,915 \mathrm{~cm}^{-1}\right)$ are attributed to the symmetric $\left(v_{1}\right)$ mode. The bands in the range $600-370 \mathrm{~cm}^{-1}$ are due to $\mathrm{PO}_{4}{ }^{3-}$ bending modes. According to previous data, the two well-defined subdivisions of 600-520 and $450-370 \mathrm{~cm}^{-1}$ arise from the antisymmetric $\left(v_{4}\right)$ and symmetric $\left(v_{2}\right)$ modes, respectively [4].

\section{CONDENSED PHOSPHATES}

\subsection{Synthesis protocols}

\subsection{1. $\underline{P}_{2} \underline{O}_{7}{ }^{4-}:$}

\section{$\mathrm{SrCrP}_{2} \mathrm{O}_{7}$}

Equimolar mixtures of the starting materials, $\mathrm{Cr}_{2} \mathrm{P}_{2} \mathrm{O}_{7}$ and $\mathrm{Sr}_{2} \mathrm{P}_{2} \mathrm{O}_{7}$ [obtained from $\mathrm{SrCO}_{3}$ and $\left(\mathrm{NH}_{4}\right)_{2} \mathrm{HPO}_{4}$ by slowly increasing the temperature to $1273 \mathrm{~K}$ ], were sealed in evacuated silica ampoules $(1 \leq 10 \mathrm{~cm}, \mathrm{~d} \leq 1.6 \mathrm{~cm})$ with iodine $(100 \mathrm{mg})$ and $\mathrm{CrP}(5 \mathrm{mg})$ as mineralizes and heated at $1223 \mathrm{~K}$ for $10 \mathrm{~d}$. The addition of $\mathrm{CrP}$ was intended to ensure reducing conditions.

Furthermore, we have observed an improved recrystallization via the gas phase, and even chemical vapor transport reactions for many phosphates, using iodine as a mineraliser/transport agent in combination with reducing agents such as metal, phosphorus or metal phosphide. The reaction products were washed with dilute $\mathrm{NaOH}$ and water, and dried at 393K. The experiments led to light blue powders of $\mathrm{SrCrP}_{2} \mathrm{O}_{7}$ which always contained small amounts of well recrystallized $\mathrm{CrP}$ and $\mathrm{Cr}_{2} \mathrm{P}_{2} \mathrm{O}_{7}$ as by-products.

Occasionally, growth of prismatic crystals of $\mathrm{SrCrP}_{2} \mathrm{O}_{7}$ with an edge-length of up to1 $\mathrm{mm}$ was observed. Chemical vapor transport experiments in a temperature gradient $(1323 \mathrm{~K} 1223 \mathrm{~K})$, aimed at purification and crystallization of $\mathrm{SrCrP}_{2} \mathrm{O}_{7}$, led to decomposition of the mixed phosphate; $\mathrm{Cr}_{2} \mathrm{P}_{2} \mathrm{O}_{7}$ was deposited at the lower temperature region, while $\mathrm{Sr}_{2} \mathrm{P}_{2} \mathrm{O}_{7}$ remained at the higher temperature zone.

$\mathrm{SrCrP}_{2} \mathrm{O}_{7}$ is remarkably stable in air and against mild oxidizing agents. By heating $\mathrm{SrCO}_{3}$ with $\mathrm{MnCO}_{3}$ or $\mathrm{ZnO}$ and stoichiometric amounts of $\left(\mathrm{NH}_{4}\right)_{2} \mathrm{HPO}_{4}$ in air slowly to $1073 \mathrm{~K}$, single-phase powders of the isotypic diphosphates $\mathrm{SrMnP}_{2} \mathrm{O}_{7}$ and $\mathrm{SrZnP}_{2} \mathrm{O}_{7}$ have also been synthesized [12].

\section{$\alpha-\mathrm{Sr}_{2} \mathbf{P}_{2} \mathbf{O}_{7}$}

Crystals of the form $\alpha$ of strontium pyrophosphate are obtained from an almost saturated solution of strontium carbonate, in a melt of sodium metaphosphate at $800^{\circ} \mathrm{C}$ [13]. $\mathrm{Sr}_{2} \mathbf{P}_{2} \mathbf{O}_{7}$

During the production of $\mathrm{Sr}_{2} \mathrm{P}_{2} \mathrm{O}_{7}$, solid powders of strontium carbonate $\left(\mathrm{SrCO}_{3}\right)$ and ammonium dihydrogen phosphate $\left(\mathrm{NH}_{4} \mathrm{H}_{2} \mathrm{PO}_{4}\right)$, from Merck and Aldrich, were used.
Stoichiometric amounts of the reactants were calculated with the help of the following formula:

$\mathrm{SrCO} 3(\mathrm{~s})+2 \mathrm{NH}_{4} \mathrm{H}_{2} \mathrm{PO}_{4}(\mathrm{~s}) \longrightarrow \mathrm{Sr}_{2} \mathrm{P}_{2} \mathrm{O}_{7}(\mathrm{~s})+3 \mathrm{H}_{2} \mathrm{O}$ (g) $+2 \mathrm{NH}_{3}(\mathrm{~g})+2 \mathrm{CO}_{2}(\mathrm{~g})$

In order to obtain $5 \mathrm{~g}$ of $\mathrm{Sr}_{2} \mathrm{P}_{2} \mathrm{O}_{7}$ product, at the beginning $4.227 \mathrm{~g}$ of $\mathrm{SrCO}_{3}$ and $3.294 \mathrm{~g}$ of $\mathrm{NH}_{4} \mathrm{H}_{2} \mathrm{PO}_{4}$ were weighed. Two materials were then mixed homogeneously in an agate mortar by grinding. The mixture was put into furnace and was heated up to $900^{\circ} \mathrm{C}$ with a heating rate of $700^{\circ} \mathrm{C} / \mathrm{hr}$. Retention time was set as $14.5 \mathrm{~h}$. At the end of this process, when the temperature was reduced to room temperature, the product was reground nicely in an agate mortar [14].

\section{$\operatorname{SrZn}\left(\mathbf{P}_{2} \mathbf{O}_{7}\right)$}

$\mathrm{SrZnP}_{2} \mathrm{O}_{7}$ powders were prepared using a conventional solidstate reaction method. High purity $\mathrm{SrCO}_{3}(99.0 \%), \mathrm{ZnO}$ $(99.5 \%)$ and $\mathrm{NH}_{4} \mathrm{H}_{2} \mathrm{PO}_{4}(99.90 \%)$ were used as raw materials. Stoichiometric mixtures of starting materials were homogenized by ball-milling with $\mathrm{ZrO}_{2}$ balls in acetone for $24 \mathrm{~h}$, and then calcined at $850-9008 \mathrm{C}$ for $2 \mathrm{~h}$ to investigate the formation process of $\mathrm{SrZnP}_{2} \mathrm{O}_{7}$ phase. The calcined powders were then milled again, dried and sieved. PVA (9wt.\%) was added into sieved powders and was granulated, and then uniaxially pressed into pellets with a diameter of $16 \mathrm{~mm}$. The compacts were sintered at a temperature range from $9008 \mathrm{C}$ to $9808 \mathrm{C}$ in order to investigate the sintering behaviors.

A mixture of $44.3 \mathrm{mg}$ [0.300 mmol; for $\left.\mathrm{Sr}_{2}\left(\mathrm{P}_{2} \mathrm{O}_{7}\right), 0.6 \mathrm{mmol}\right]$ of strontium carbonate (Alfa Aesar, 97.5\%), $24.3 \mathrm{mg}$ [0.300 $\mathrm{mmol}$; only for $\left.\mathrm{SrZn}\left(\mathrm{P}_{2} \mathrm{O}_{7}\right)\right]$ of zinc oxide, $1.0 \mathrm{mg}(0.003$ mmol, doping concn 1.9\%) of europium oxide $\mathrm{Eu}_{2} \mathrm{O}_{3}$ (KristallhandelKelpin, 99.9\%), $2.5 \mathrm{mg}(0.013 \mathrm{mmol}$, doping concn $4.3 \%$ ) of manganese nitrate $\mathrm{Mn}\left(\mathrm{NO}_{3}\right)_{2} \cdot 4 \mathrm{H}_{2} \mathrm{O}$ (Merck, $98.5 \%)$, and $83.2 \mathrm{mg}(0.630 \mathrm{mmol})$ of ammonium dihydrogen phosphate (ABCR, 98\%) was transferred into an alumina boat. The latter was then heated under a hydrogen/nitrogen (10/90) flow $\left(2 \mathrm{Lh}^{-1}\right)$ to $1070 \mathrm{~K}$ at a rate of $60 \mathrm{Kh}^{-1}$. After $18 \mathrm{~h}$, the mixture was cooled to room temperature at a rate of $180 \mathrm{Kh}^{-1}$. Finally, $\operatorname{SrM}\left(\mathrm{P}_{2} \mathrm{O}_{7}\right): \mathrm{Eu}, \mathrm{Mn}$ was obtained quantitatively as a crystalline, colorless, and non-hygroscopic powder. According to their powder diffraction patterns, all samples presented herein were singlephase. The composition of obtained samples was checked by energy-dispersive X-ray spectroscopy and confirmed the respective $\mathrm{M} / \mathrm{P}$ (M ) $\mathrm{Sr}, \mathrm{Zn}$ ) ratios[15].

\section{$\mathrm{SrNiP}_{2} \mathrm{O}_{7}$ et $\mathrm{SrNi}_{3}\left(\mathbf{P}_{2} \mathbf{O}_{7}\right)_{2}$}

Powder samples of $\mathrm{SrNiP}_{2} \mathrm{O}_{7}$ and $\mathrm{ANi}_{3}\left(\mathrm{P}_{2} \mathrm{O}_{7}\right)_{2}(\mathrm{~A}=\mathrm{Ca}, \mathrm{Sr}$, $\mathrm{Ba}), 2 \mathrm{~g}$ each, were synthesized from stoichiometric amounts of nickel, alcaline earth carbonate and $\left(\mathrm{NH}_{4}\right)_{2} \mathrm{HPO}_{4}$. After dissolution of the starting materials in nitric acid the homogenous solutions have been evaporated to dryness on a heating stirrer. The residues were ground and heated in air at increasing temperatures $(600,800,1000$ and finally to $1100^{\circ} \mathrm{C}$ ), each period lasting one day. The purity of thus obtained powder samples has been controlled by Guinier photographs. The colours of the powdery materials vary from red-orange $\left(\mathrm{SrNiP}_{2} \mathrm{O}_{7}\right)$ over pale orange-yellow 
Rachida Oubouaza et al., International Journal of Emerging Trends in Engineering Research, 8(9), September 2020, 6587 - 6598

$\left(\mathrm{BaNi}_{3}\left(\mathrm{P}_{2} \mathrm{O}_{7}\right)_{2}\right)$, yellow $\left(\mathrm{SrNi}_{3}\left(\mathrm{P}_{2} \mathrm{O}_{7}\right)_{2}\right)$ to pale yellow $\left(\mathrm{CaNi}_{3}\left(\mathrm{P}_{2} \mathrm{O}_{7}\right)_{2}\right)$.

Single crystals of $\mathrm{SrNiP}_{2} \mathrm{O}_{7}$ and $\mathrm{SrNi}_{3}\left(\mathrm{P}_{2} \mathrm{O}_{7}\right)_{2}$ have been obtained by a different procedure. A mixture of $\mathrm{SrCO}_{3}$ $(4.4288 \mathrm{~g}, 3 \mathrm{mmol}), \mathrm{NiO}(2.2410 \mathrm{~g}, 3 \mathrm{mmol})$ and $\left(\mathrm{NH}_{4}\right)_{2} \mathrm{HPO}_{4}(7.9233 \mathrm{~g}, 6 \mathrm{mmol})$ was ground thoroughly in a mortar and transferred to a ceramic crucible. The sample was then heated to $1173 \mathrm{~K}$ in a tube furnace, to effect decomposition of the carbonate, followed by melting (1473 $\mathrm{K}$ ) in a platinium crucible. After controlled cooling (rate $10^{\circ} \mathrm{C} . \mathrm{h}^{-1}$ ) to $773 \mathrm{~K}$ the sample was quenched to room temperature. The product was found to contain red-orange crystals of $\mathrm{SrNiP}_{2} \mathrm{O}_{7}$ and a few yellowishgreen ones, which turned out to be $\mathrm{SrNi}_{3}\left(\mathrm{P}_{2} \mathrm{O}_{7}\right)_{2}$ [16].

\section{$\mathrm{SrFeP}_{2} \mathrm{O}_{7}$}

Single crystals of $\mathrm{SrFeP}_{2} \mathrm{O}_{7}$ were obtained by hydrothermal growth starting from the reactants $\mathrm{SrF}_{2}$ and $\mathrm{Fe}_{2} \mathrm{O}_{3}$ in the molar ratio 2:1 in an aqueous solution of phosphoric acid (7 $\mathrm{M}$ ). The mixture was sealed in a platinum tube (filling level $40 \%$ ) and heated at $956 \mathrm{~K}$ for $24 \mathrm{~h}$. The maximum pressure reached was $186 \mathrm{MPa}$. The resulting product was filtered off, washed with distilled water and dried in air at room temperature. The main by-product was unreacted $\mathrm{SrF}_{2}$ [17].

\section{$(\mathrm{M}, \mathrm{Cu}) \mathrm{P}_{2} \mathrm{O}_{7}(\mathrm{M}=\mathrm{Mg}, \mathrm{Ca}, \mathrm{Sr})$}

The solid-solution $\mathrm{M}_{2-\mathrm{x}} \mathrm{Cu}_{\mathrm{x}} \mathrm{P}_{2} \mathrm{O}_{7}$ with $\mathrm{M}=\mathrm{Mg}, \mathrm{Ca}, \mathrm{Sr}$, and $\mathrm{Ba}(0 \leq \mathrm{x} \leq 2)$ were prepared at $1173 \mathrm{~K}$ from powder starting materials $\mathrm{M}_{2} \mathrm{P}_{2} \mathrm{O}_{7}$ and $\mathrm{Cu}_{2} \mathrm{P}_{2} \mathrm{O}_{7}$ which are obtained by two processes :The dry and wet methods.

Dry method. Stoichiometric amounts of diammonium phosphate $\left(\mathrm{NH}_{4}\right)_{2} \mathrm{HPO}_{4}$ and oxide $(\mathrm{MgO}, \mathrm{CuO})$ or carbonate $\left(\mathrm{CaCO}_{3}, \mathrm{SrCO}, \mathrm{BaCO}\right.$, ) were mixed, ground in a mortar, and then heated slowly to $1173 \mathrm{~K}$ in an alumina crucible. Several heatings of pressed pellets were used to obtain pure powders.

Wet method. The starting diphosphates could be prepared also by precipitation from an aqueous solution $\mathrm{Na}_{4} \mathrm{P}_{2} \mathrm{O}_{7}$ with an excess of metal nitrate or chloride. The precipitate was filtered, washed with cold water and then heated at $1173 \mathrm{~K}$ [18].

\section{$\mathrm{SrCoP}_{2} \mathrm{O}_{7}$}

Crystals were synthesized from a mixture of $\mathrm{SrCO}_{3}, \mathrm{CoCO}_{3}$ and $\left(\mathrm{NH}_{4}\right)_{2} \mathrm{HPO}_{4}$ in stoichiometric ratios, heated first in air at $893 \mathrm{~K}$ to decompose the phosphate and carbonates. After grinding, the resulting product was heated for several days at $1323 \mathrm{~K}$ in an evacuated silica ampoule [19].

\section{$\mathrm{CdSrP}_{2} \mathrm{O}_{7}$}

Single crystals of $\mathrm{CdSrP}_{2} \mathrm{O}_{7}(\mathrm{I})$ were prepared by heating a stoichiometric mixture of $\mathrm{CdCO}_{3}, \mathrm{SrCO}_{3}$, and $\left(\mathrm{NH}_{4}\right)_{2} \mathrm{HPO}_{4}$ to liquid state $(1350 \mathrm{~K})$ in a platinum carrier, followed by a period of slow cooling $\left(4 \mathrm{Kh}^{-1}\right)$ to $1170 \mathrm{~K}$ and further cooling $\left(10 \mathrm{Kh}^{-1}\right)$ to $473 \mathrm{~K}[20]$.

\section{$\mathrm{SrMgP}_{2} \mathrm{O}_{7}$}

A powder has been prepared, according to the chemical formula $\mathrm{SrMgP}_{2} \mathrm{O}_{7}$, starting from equimolar mixtures of the starting materials $\mathrm{SrCO}_{3}, \mathrm{MgCO}_{3}$ and $\left(\mathrm{NH}_{4}\right)_{2} \mathrm{HPO}_{4}$. The mixture was heated progressively in air at increasing temperatures up to $1173 \mathrm{~K}$ [21].

\section{$\mathrm{SrK}_{2} \mathbf{P}_{2} \mathrm{O}_{7}, \mathrm{SrRb}_{2} \mathbf{P}_{2} \mathrm{O}_{7}$, and $\mathrm{SrCs}_{2} \mathbf{P}_{2} \mathrm{O}_{7}$}

Single crystals of the potassium salt(melting point : $\mathrm{mp}=$ $1348 \mathrm{~K}$ ) were prepared by slow cooling of a melt prepared from a stoichiometric mixture of $\mathrm{K}_{2} \mathrm{CO}_{3}, \mathrm{SrCO}_{3}$, and $\mathrm{NH}_{4} \mathrm{H}_{2} \mathrm{PO}_{4}$ first heated at $773 \mathrm{~K}$ for 30 hbefore melting. A complete determination of the atomic arrangement was reported. This compound is isotypic with $\mathrm{CaK}_{2} \mathrm{As}_{2} \mathrm{O}_{7}$. The same authors performed the crystal structure determination of $\mathrm{SrRb}_{2} \mathrm{P}_{2} \mathrm{O}_{7}$ and $\mathrm{SrCs}_{2} \mathrm{P}_{2} \mathrm{O}_{7}$. These last two compounds are isotypic but not is amorphous with the potassium salt [1].

\section{* Crystallographic data}

Table 3: Main Crystallographic Data for the Monophosphates associated to strontium

\begin{tabular}{|c|c|c|c|c|c|}
\hline Formula & $\begin{array}{c}\mathrm{a}(\AA) \\
\left.\alpha^{\circ}\right)\end{array}$ & $\begin{array}{c}\mathrm{b}(\AA) \\
\beta^{\circ}\end{array}$ & $\begin{array}{c}c(\AA) \\
\gamma^{\circ}\end{array}$ & $\begin{array}{l}\text { Space } \\
\text { Group }\end{array}$ & $\mathrm{Z}$ \\
\hline $\begin{array}{c}\mathrm{SrCrP}_{2} \mathrm{O}_{7} \\
\text { (monoclinic) }\end{array}$ & 5.422 & $\begin{array}{c}8.3254 \\
90.39\end{array}$ & 12.542 & $\mathrm{P} 2_{1} / \mathrm{n}$ & 4 \\
\hline $\begin{array}{c}\alpha-\mathrm{Sr}_{2} \mathrm{P}_{2} \mathrm{O}_{7} \\
\text { (orthorhombic) }\end{array}$ & 8,9104 & 5,4035 & 13,1054 & $\mathrm{Pna2}_{1}$ & 4 \\
\hline $\begin{array}{c}\mathrm{Sr}_{2} \mathrm{P}_{2} \mathrm{O}_{7} \\
\text { (orthorhombic) }\end{array}$ & 8.9459 & 5.4133 & 13.2114 & Pnma & 4 \\
\hline $\begin{array}{l}\mathrm{SrZn}\left(\mathrm{P}_{2} \mathrm{O}_{7}\right) \\
\text { (monoclinic) }\end{array}$ & 5,31 & 8.2 & 12.72 & $\mathrm{P} 2_{1} / \mathrm{n}$ & 4 \\
\hline $\mathrm{SrNiP}_{2} \mathrm{O}_{7}$ & 5.2691 & $\begin{array}{l}8.2674 \\
90.246\end{array}$ & 12.6140 & $\mathrm{P} 2_{1} / \mathrm{n}$ & 4 \\
\hline $\mathrm{SrNi}_{3}\left(\mathrm{P}_{2} \mathrm{O}_{7}\right)_{2}$ & 7.4092 & 7.6594 & 9.4474 & $\mathrm{P} 21 / \mathrm{c}$ & 2 \\
\hline $\mathrm{SrCoP}_{2} \mathrm{O}_{7}$ & 5.3165 & $\begin{array}{l}8.2574 \\
90.133\end{array}$ & 12.6755 & $\mathrm{P} 2 / \mathrm{n}$ & 4 \\
\hline $\mathrm{SrCuP2O} 7$ & 12.455 & $\begin{array}{l}8.129 \\
90.59\end{array}$ & 5.369 & $\mathrm{P} 21 / \mathrm{c}$ & 4 \\
\hline $\mathrm{SrCdP}_{2} \mathrm{O}_{7}$ & 5.414 & $\begin{array}{l}8.615 \\
90.01\end{array}$ & 12.878 & $\mathrm{P} 2_{1} / \mathrm{n}$ & 4 \\
\hline $\mathrm{SrMgP}_{2} \mathrm{O}_{7}$ & 5.309 & $\begin{array}{l}8.299 \\
10.06\end{array}$ & 12.68 & $\mathrm{P} 2_{1} / \mathrm{n}$ & 4 \\
\hline $\mathrm{SrZnP}_{2} \mathrm{O}_{7}$ & 5.299 & $\begin{array}{c}8.189 \\
90.0\end{array}$ & 12.72 & $\mathrm{P} 2_{1} / \mathrm{n}$ & 4 \\
\hline $\mathrm{SrFeP}_{2} \mathrm{O}_{7}$ & 5.370 & $\begin{array}{l}8.268 \\
90.37\end{array}$ & 12.693 & $\mathrm{P} 2_{1} / \mathrm{n}$ & 4 \\
\hline $\mathrm{SrK}_{2} \mathrm{P}_{2} \mathrm{O}_{7}$ & 9.168 & $\begin{array}{c}5.712 \\
105.79\end{array}$ & 14.720 & $\mathrm{P} 21 / \mathrm{c}$ & 4 \\
\hline $\mathrm{SrRb}_{2} \mathrm{P}_{2} \mathrm{O}_{7}$ & 10.270 & $\begin{array}{c}5.867 \\
116.48\end{array}$ & 14.413 & $\mathrm{C} 2 / \mathrm{c}$ & 4 \\
\hline $\mathrm{SrCs}_{2} \mathrm{P}_{2} \mathrm{O}_{7}$ & 10.528 & $\begin{array}{c}6.081 \\
118.34\end{array}$ & 14.766 & $\mathrm{C} 2 / \mathrm{c}$ & 4 \\
\hline
\end{tabular}




\section{*Characterization of $\mathbf{P}_{2} \mathrm{O}_{7}{ }^{4-}$ in $\mathrm{Sr}_{2} \mathbf{P}_{2} \mathrm{O}_{7}$ by IR vibration} spectrometry.

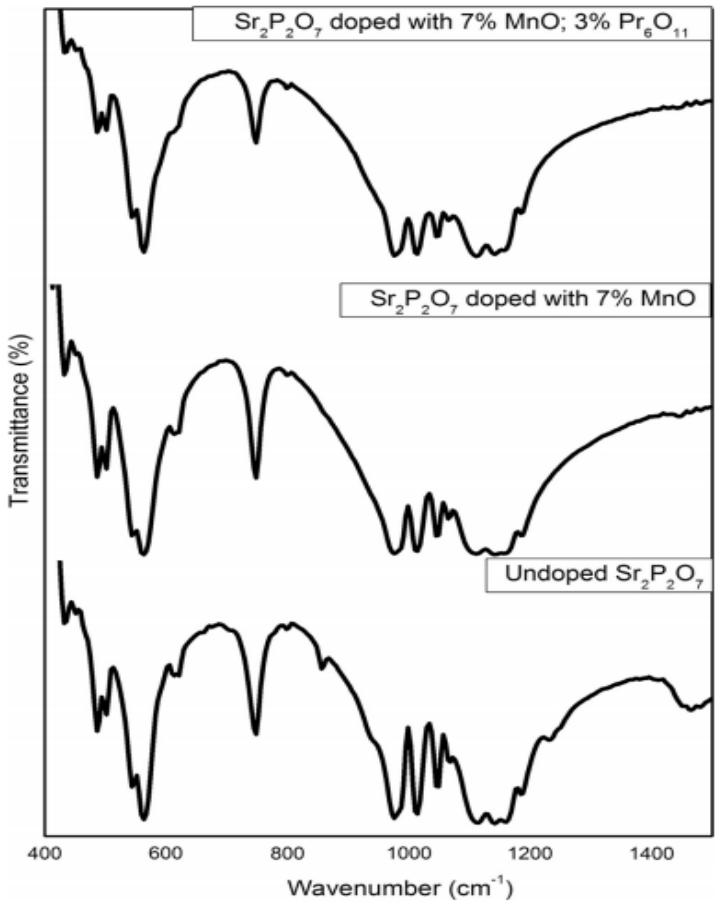

Figure 2. FTIR analysis of undoped, $\mathrm{MnO}$ and $\mathrm{MnO}-\mathrm{Pr}_{6} \mathrm{O}_{11}$ doped $\mathrm{Sr}_{2} \mathrm{P}_{2} \mathrm{O}_{7}$ samples [14].

Table 4: IR Frequency characteristics (in $\mathrm{cm}^{-1}$ ) for $\mathrm{P}_{2} \mathrm{O}_{7}^{4-}$ anions [43]

\begin{tabular}{|c|c|}
\hline Vibrations & Frequencies $\left(\mathrm{cm}^{-1}\right)$ \\
\hline & 1060 \\
\hline $\boldsymbol{v}_{\text {as }}\left(\mathbf{P O}_{3}\right)$ & 1000 \\
\hline $\mathbf{v}_{\mathbf{s}}\left(\mathbf{P O}_{\mathbf{3}}\right)$ & 1000 \\
& 900 \\
\hline $\boldsymbol{v}_{\text {as }}(\mathbf{P O P})$ & 825 \\
& 700 \\
\hline $\boldsymbol{\delta}_{\text {as }}\left(\mathbf{P O}_{3}\right)$ & 656 \\
\hline $\boldsymbol{\delta}_{\mathbf{s}}\left(\mathbf{P O}_{3}\right)$ & 535 \\
& 520 \\
& 420 \\
\hline
\end{tabular}

In Fig.2, FTIR analysis of samples undoped $\mathrm{Sr}_{2} \mathrm{P}_{2} \mathrm{O}_{7}$ and doped with $\mathrm{MnO}$ and $\mathrm{Pr}_{6} \mathrm{O}_{11}$ are given. $\mathrm{P}_{2} \mathrm{O}_{7}{ }^{4-}$ vibrational modes were observed within the range of $1500-400 \mathrm{~cm}^{-1}$ which was consistent with the literature. The anion $\mathrm{P}_{2} \mathrm{O}_{7}{ }^{4-}$ contains the $\mathrm{PO}_{3}{ }^{2-}$ radical and the $\mathrm{P}-\mathrm{O}-\mathrm{P}$ bridge. For the symmetrical and asymmetrical stretching, frequencies are expected within 900-1000 and 1000- $1100 \mathrm{~cm}^{-1}$.

In Fig. 2, which is the FTIR of strontium pyrophosphate sample, peaks of asymetrical $\mathrm{PO}_{3}{ }^{2-}$ radical bending mode was seen around 1000 and $1060 \mathrm{~cm}^{-1}$. The P-O-P bridge peaks were observed around $700-825 \mathrm{~cm}^{-1}$. These peaks proved the presence of pyrophosphate within the structure.
In the IR plot of undoped $\mathrm{Sr}_{2} \mathrm{P}_{2} \mathrm{O}_{7}$, the band around $1400 \mathrm{~cm}^{-}$ ${ }^{1}$ can be assigned as the remaining impurity of dibasic orthophosphate, $\mathrm{HPO}_{4}{ }^{2-}$ which is common in pyrophosphate formation and not present in the doped samples which were heated at higher temperature than undoped samples for longer time. The overall peak structure was consistent with the undoped strontium pyrophosphate structural peaks.

\subsection{2. $\mathrm{P}_{3} \mathrm{O}_{10}{ }^{5-}$}

\section{$\mathrm{Sr}_{3} \mathbf{P}_{3} \mathbf{O}_{10} \mathrm{Cl}$}

The chemicals used in this work were all analytical-grade and were purchased from commercial suppliers and used without further purification. $\mathrm{P}_{2} \mathrm{O}_{5}$ (Aldrich, 98\%), $\mathrm{MgO}$ (Alfa Aesar, 99.9\%), $\mathrm{SrCl}_{2}$ (Alfa Aesar, 99.9\%), SrO (Alfa Aesar, 99.9\%), and $\mathrm{NaCl}$ (Alfa Aesar, 99.9\%), $\mathrm{SrCO}_{3}$ (Alfa Aesar, 99.9\%), $\mathrm{NH}_{4} \mathrm{H}_{2} \mathrm{PO}_{4}$ (Alfa Aesar,99.9\%).

Crystals of title compound were grown by employing the $\mathrm{NaCl}$ and $\mathrm{SrCl}_{2}$ flux in a fused quartz ampule. The reactants were ground and loaded in an Ar purged drybox and then flame-sealed under vacuum prior to heating. In the reaction, $\mathrm{MgO}, \mathrm{SrO}$ and $\mathrm{P}_{2} \mathrm{O}_{5}$ were mixed in a $2: 1: 3 \mathrm{~mol}$ ratio (ca. $\sim 0.3$ g) and added to a $\mathrm{SrCl}_{2} / \mathrm{NaCl}$ (in a 1:1 mol ratio) eutectic flux equal to 3 times the mass of oxides reactants.

The mixture were heated to $850^{\circ} \mathrm{C}$ at a rate of $3^{\circ} \mathrm{C} / \mathrm{min}$, held for $12 \mathrm{~h}$, and then slowly cooled, at a rate of $0.1^{\circ} \mathrm{C} / \mathrm{min}$, to $300^{\circ} \mathrm{C}$, followed by furnace-cooling. The colorless transparent crystals were retrieved from the flux by washing the products with deionized water using suction filtration. The colorless crystals were collected with about $20 \%$ yield (based on P). The crystals appear to be relatively stable in air and water [22].

\subsection{3. $\mathrm{P}_{4} \mathrm{O}_{13}{ }^{6-}, \mathrm{P}_{5} \mathrm{O}_{16}{ }^{7-}$}

Until now, there are no oligophosphate associated to strontium for such anions $\mathrm{P}_{4} \mathrm{O}_{13}{ }^{6-}$ and $\mathrm{P}_{5} \mathrm{O}_{16}{ }^{7-}$.

\subsection{Cyclophosphates $\left(\mathrm{P}_{\mathrm{n}} \mathrm{O}_{3 \mathrm{n}}\right)^{\mathrm{n}-}$}

\subsection{1. $\mathrm{P}_{3} \mathrm{O}_{9}{ }^{3-}$}

\section{$\mathrm{SrKP}_{3} \mathrm{O}_{9} \cdot 3 \mathrm{H}_{2} \mathrm{O}$}

Polycrystalline samples of $\mathrm{SrKP}_{3} \mathrm{O}_{9} \cdot 3 \mathrm{H}_{2} \mathrm{O}$ are prepared by adding dilute cyclotriphosphoric acid to an aqueous solution of strontium carbonate and potassium carbonate with a stoichiometric ratio $\mathrm{Sr} / \mathrm{K}=1$, according to the following chemical reaction:

$\mathrm{H}_{3} \mathrm{P}_{3} \mathrm{O}_{9}+\mathrm{SrCO}_{3}+1 / 2 \mathrm{~K}_{2} \mathrm{CO}_{3}+3 / 2 \mathrm{H}_{2} \mathrm{O} \rightarrow \mathrm{SrKP}_{3} \mathrm{O}_{9} \cdot 3 \mathrm{H}_{2} \mathrm{O}+$ $3 / 2 \mathrm{CO}_{2}$

The so-obtained solution is then slowly evaporated at room temperature until polycrystalline samples of $\mathrm{SrKP}_{3} \mathrm{O}_{9} \cdot 3 \mathrm{H}_{2}$ Oare obtained. The cyclotriphosphoric acid used in this reaction was prepared from an aqueous solution of $\mathrm{Na}_{3} \mathrm{P}_{3} \mathrm{O}_{9}$ passed through an ion-exchange resin "Amberlite IR 120" [23]. 
Rachida Oubouaza et al., International Journal of Emerging Trends in Engineering Research, 8(9), September 2020, 6587 - 6598

\section{$\mathrm{SrKP}_{3} \mathrm{O}_{9}$}

A Polycrystalline sample of $\mathrm{SrKP}_{3} \mathrm{O}_{9}$ was obtained as polycrystalline samples by total dehydration of $\mathrm{SrKP}_{3} \mathrm{O}_{9} \cdot 3 \mathrm{H}_{2} \mathrm{O}$ under atmospheric pressure between 250 and $350^{\circ} \mathrm{C}$ according to the following chemical reaction [23] $\mathrm{SrKP}_{3} \mathrm{O}_{9} \cdot 3 \mathrm{H}_{2} \mathrm{O}$ $\mathrm{SrKP}_{3} \mathrm{O}_{9}+3 \mathrm{H}_{2} \mathrm{O}$

\section{$\mathrm{SrNH}_{4} \mathrm{P}_{3} \mathrm{O}_{9} \cdot 3 \mathrm{H}_{2} \mathrm{O}$}

$\mathrm{SrNH}_{4} \mathrm{P}_{3} \mathrm{O}_{9} \cdot 3 \mathrm{H}_{2} \mathrm{O}$ was prepared by the metathesis reaction of Boulle using silver cyclotriphosphate monohydrate as starting material. An aqueous solution of $\mathrm{SrCl}_{2} \cdot 6 \mathrm{H}_{2} \mathrm{O}$ and $\mathrm{NH}_{4} \mathrm{Cl}$ in stoichiometric proportions is added with the corresponding amount of $\mathrm{Ag}_{3} \mathrm{P}_{3} \mathrm{O}_{9} \cdot \mathrm{H}_{2} \mathrm{O}$, according to the following chemical reaction [24]

$\mathrm{SrCl}_{2} \cdot 6 \mathrm{H}_{2} \mathrm{O}+\mathrm{NH}_{4} \mathrm{Cl}+\mathrm{Ag}_{3} \mathrm{P}_{3} \mathrm{O}_{9} \longrightarrow$

$\mathrm{H}_{2} \mathrm{OSrNH}_{4} \mathrm{P}_{3} \mathrm{O}_{9} \cdot 3 \mathrm{H}_{2} \mathrm{O}+3 \mathrm{AgCl}$

After filtration, to eliminate the insoluble silver chloride, the resulting solution is kept at room temperature until the formation of prismatic crystals of $\mathrm{SrNH}_{4} \mathrm{P}_{3} \mathrm{O}_{9} \cdot 3 \mathrm{H}_{2} \mathrm{O}$ with hexagonal section.

\section{$\mathrm{SrTIP}_{3} \mathrm{O}_{9} \cdot 3 \mathrm{H}_{2} \mathrm{O}$}

Polycrystalline samples of $\mathrm{SrTlP}_{3} \mathrm{O}_{9} \cdot 3 \mathrm{H}_{2} \mathrm{O}$ were prepared by the method of ion exchange resin"Amberlite IR 120" with a stoichiometric ratio $\mathrm{Sr}: \mathrm{K}=1$, according to the following chemical reaction [25]

$\mathrm{H}_{3} \mathrm{P}_{3} \mathrm{O}_{9}+\mathrm{SrCO}_{3}+1 / 2 \mathrm{Tl}_{2} \mathrm{CO}_{3}+3 / 2 \mathrm{H}_{2} \mathrm{O} \rightarrow \mathrm{SrTlP}_{3} \mathrm{O}_{9} \cdot 3 \mathrm{H}_{2} \mathrm{O}$ $+3 / 2 \mathrm{CO}_{2}$

\section{$\mathrm{SrTIP}_{3} \mathrm{O}_{9}$}

A Polycrystalline sample of $\mathrm{SrKP}_{3} \mathrm{O}_{9}$ was obtained as polycrystalline samples by total dehydration of $\mathrm{SrKP}_{3} \mathrm{O}_{9} \cdot 3 \mathrm{H}_{2} \mathrm{O}$ under atmospheric pressure between 300 and $650^{\circ} \mathrm{C}$ according to the following chemical reaction [25] $\mathrm{SrTlP}_{3} \mathrm{O}_{9} \cdot 3 \mathrm{H}_{2} \mathrm{O} \longrightarrow \mathrm{SrTlP}_{3} \mathrm{O}_{9}+3 \mathrm{H}_{2} \mathrm{O}$

\section{$\mathrm{SrNaP}_{3} \mathrm{O}_{9 .} . \mathrm{H}_{2} \mathrm{O}$}

Polycrystalline samples of $\mathrm{SrNaP}_{3} \mathrm{O}_{9} \cdot 3 \mathrm{H}_{2} \mathrm{O}$ were prepared by the method of ion exchange resin "Amberlite IR 120" with a stoichiometric ratio $\mathrm{Sr} / \mathrm{K}=1$, according to the followingchemical reaction [27] :

$\mathrm{H}_{3} \mathrm{P}_{3} \mathrm{O}_{9}+\mathrm{SrCO}_{3}+1 / 2 \mathrm{Na}_{2} \mathrm{CO}_{3}+3 / 2 \mathrm{H}_{2} \mathrm{O} \rightarrow \mathrm{SrNaP}_{3} \mathrm{O}_{9} \cdot 3 \mathrm{H}_{2} \mathrm{O}$ $+3 / 2 \mathrm{CO}_{2}$

$\mathrm{Sr}_{3}\left(\mathrm{P}_{3} \mathrm{O}_{9}\right)_{2} \cdot \mathbf{7} \mathrm{H}_{2} \mathrm{O}$

Polycrystalline Sample of the title compound, $\mathrm{Sr}_{3}\left(\mathrm{P}_{3} \mathrm{O}_{9}\right)_{2} .7 \mathrm{H}_{2} \mathrm{O}$ was prepared by adding slowly dilute cyclotriphosphoric acid to aqueous solutions of strontium carbonate according to the following chemical reaction [28] $2 \mathrm{H}_{3} \mathrm{P}_{3} \mathrm{O}_{9}+3 \mathrm{SrCO}_{3}+4 \mathrm{H}_{2} \mathrm{O} \rightarrow \mathrm{Sr}_{3}\left(\mathrm{P}_{3} \mathrm{O}_{9}\right)_{2} .7 \mathrm{H}_{2} \mathrm{O}+3 \mathrm{CO}_{2}$ The so-obtained solution was then slowly evaporated at room temperature until a polycrystalline sample of $\mathrm{Sr}_{3}\left(\mathrm{P}_{3} \mathrm{O}_{9}\right)_{2} .7 \mathrm{H}_{2} \mathrm{O}$ was obtained.

\section{$\mathrm{SrRbP}_{3} \mathrm{O}_{\mathbf{9}} \cdot \mathbf{3 H}_{\mathbf{2}} \mathrm{O}$}

Polycrystalline samples of $\mathrm{SrRbP}_{3} \mathrm{O}_{9} \cdot 3 \mathrm{H}_{2} \mathrm{O}$ were prepared by the method of ion exchange resin with a stoichiometric ratio $\mathrm{Sr} / \mathrm{Rb}=1$, according to the following chemical reaction [29] $\mathrm{H}_{3} \mathrm{P}_{3} \mathrm{O}_{9}+\mathrm{SrCO}_{3}+1 / 2 \mathrm{Rb}_{2} \mathrm{CO}_{3}+3 / 2 \mathrm{H}_{2} \mathrm{O} \rightarrow \mathrm{SrRbP}_{3} \mathrm{O}_{9} \cdot 3 \mathrm{H}_{2} \mathrm{O}$ $+3 / 2 \mathrm{CO}_{2}$.

\section{$\mathrm{SrRbP}_{3} \mathrm{O}_{9}$}

$\mathrm{SrRbP}_{3} \mathrm{O}_{9}$ was obtained as polycrystalline samples by total dehydration of $\mathrm{SrRbP}_{3} \mathrm{O}_{9} \cdot 3 \mathrm{H}_{2} \mathrm{O}$ under atmospheric pressure between 300 and $400{ }^{\circ} \mathrm{C}$ according to the following chemical reaction [29].

$\mathrm{SrRbP}_{3} \mathrm{O}_{9} \cdot 3 \mathrm{H}_{2} \mathrm{O} \longrightarrow \mathrm{SrRbP}_{3} \mathrm{O}_{9}+3 \mathrm{H}_{2} \mathrm{O}$.

With further increase in temperature, $\mathrm{SrRbP}_{3} \mathrm{O}_{9}$ was found to be stable and then melted at $760^{\circ} \mathrm{C}$.

\section{$\mathrm{MnSr}_{2}\left(\mathrm{P}_{3} \mathrm{O}_{9}\right)_{2} \cdot \mathbf{4} \mathrm{H}_{2} \mathrm{O}$}

Through a column of ion exchange resin $\left(\mathrm{Na}^{+}\right.$by $\left.\mathrm{H}^{+}\right)$, "Amberlite IR 120" . A concentrated solution of $\mathrm{Na}_{3} \mathrm{P}_{3} \mathrm{O}_{9}$ is slowly added. The cyclotriphosphoric acid $\mathrm{H}_{3} \mathrm{P}_{3} \mathrm{O}_{9}$ thus obtained is immediately neutralized with a mixture of stoichiometric amounts of carbonates [26], $\mathrm{MnCO}_{3}$ and $\mathrm{SrCO}_{3}$, according to the following chemical reaction:

$2 \mathrm{H}_{3} \mathrm{P}_{3} \mathrm{O}_{9}+2 \mathrm{SrCO}_{3}+\mathrm{MnCO}_{3}+\mathrm{H}_{2} \mathrm{O} \longrightarrow$

$\mathrm{MnSr}_{2}\left(\mathrm{P}_{3} \mathrm{O}_{9}\right)_{2} \cdot 4 \mathrm{H}_{2} \mathrm{O}+3 \mathrm{CO}_{2}$

The solution abandoned for a few days, $\mathrm{MnSr}_{2}\left(\mathrm{P}_{3} \mathrm{O}_{9}\right)_{2} \cdot 4 \mathrm{H}_{2} \mathrm{O}$

is obtained in the form of crystals and powder having a

pinkish white color [30,44].

* Crystallographic data

Table 5: Main Crystallographic Data for the cyclotriphosphates associated to strontium

\begin{tabular}{|c|c|c|c|c|c|}
\hline Formula & $\begin{array}{c}\mathrm{a}(\AA) \\
\alpha^{\circ}\end{array}$ & $\begin{array}{c}\mathrm{b}(\AA) \\
\left.\beta^{\circ}\right)\end{array}$ & $\begin{array}{c}\mathrm{c}(\AA) \\
\gamma^{\circ}\end{array}$ & $\begin{array}{l}\text { Space } \\
\text { Group }\end{array}$ & $\mathrm{Z}$ \\
\hline $\mathrm{SrKP}_{3} \mathrm{O}_{9} \cdot 3 \mathrm{H}_{2} \mathrm{O}$ & 9.082 & 8.133 & 15.009 & Pnma & 4 \\
\hline $\mathrm{SrKP}_{3} \mathrm{O}_{9}$ & 14.957 & $\begin{array}{c}8.372 \\
102.27 \\
\end{array}$ & 7.909 & $\begin{array}{l}P 2_{1} / m \\
\text { or } P 2_{1}\end{array}$ & 4 \\
\hline $\mathrm{SrNH}_{4} \mathrm{P}_{3} \mathrm{O}_{9} \cdot 3 \mathrm{H}_{2} \mathrm{O}$ & 9.126 & 8.157 & 15.256 & Pnma & 4 \\
\hline $\mathrm{SrTlP}_{3} \mathrm{O}_{9} \cdot 3 \mathrm{H}_{2} \mathrm{O}$ & 9.147 & 8.180 & 15.458 & Pnma & 4 \\
\hline $\mathrm{SrTlP}_{3} \mathrm{O}_{9}$ & 14.544 & 8.639 & 7.727 & $\begin{array}{l}\mathrm{P} 2_{1} / \mathrm{m} \\
\text { or } \mathrm{P} 2_{1}\end{array}$ & 4 \\
\hline $\mathrm{MnSr}_{2}\left(\mathrm{P}_{3} \mathrm{O}_{9}\right)_{2} \cdot 4 \mathrm{H}_{2} \mathrm{O}$ & 6.653 & 7.110 & 5.123 & $\mathrm{P}-1$ & 1 \\
\hline $\mathrm{SrNaP}_{3} \mathrm{O}_{9} .3 \mathrm{H}_{2} \mathrm{O}$ & 16,167 & 12,013 & 10,645 & Pnma & 4 \\
\hline $\mathrm{Sr}_{3}\left(\mathrm{P}_{3} \mathrm{O}_{9}\right)_{2} .7 \mathrm{H}_{2} \mathrm{O}$ & 16.05 & 12.33 & 10.87 & Pnma & 4 \\
\hline $\mathrm{SrRbP}_{3} \mathrm{O}_{9}$ & 14.958 & 8.503 & 8.503 & $\begin{array}{c}\mathrm{P} 2_{1} \\
/ \mathrm{m} \text { or } \\
\mathrm{P} 2_{1} \\
\end{array}$ & 4 \\
\hline $\mathrm{SrRbP}_{3} \mathrm{O}_{9} \cdot 3 \mathrm{H}_{2} \mathrm{O}$ & 9.120 & 8.141 & 15.234 & Pnma & 4 \\
\hline $\mathrm{MnSr}_{2}\left(\mathrm{P}_{3} \mathrm{O}_{9}\right)_{2} \cdot 4 \mathrm{H}_{2} \mathrm{O}$ & $\begin{array}{c}6,653 \\
103,37\end{array}$ & $\begin{array}{l}7,110 \\
95,81\end{array}$ & $\begin{array}{l}5,123 \\
93,04\end{array}$ & P-1 & 1 \\
\hline
\end{tabular}


* Characterization of $\mathrm{P}_{3} \mathrm{O}_{9}{ }^{3-}$ inSrKP $\mathrm{P}_{3} \mathrm{O}_{9} \cdot 3 \mathrm{H}_{2} \mathrm{Oby}$ IR vibration spectrometry

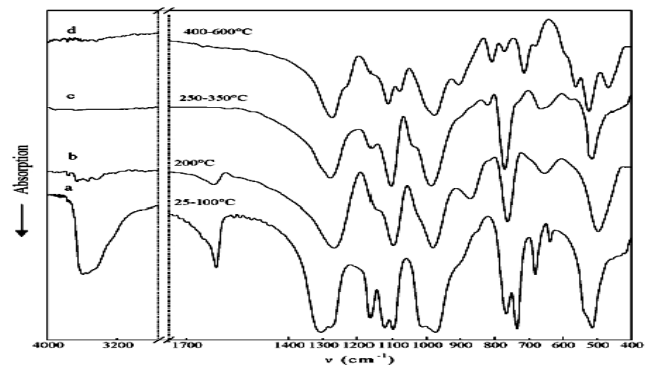

Fig. 3. IR spectra of the phosphates (a) $\mathrm{SrKP}_{3} \mathrm{O}_{9} \cdot 3 \mathrm{H}_{2} \mathrm{O}$, (b) amorphous phase,(c) $\mathrm{SrKP}_{3} \mathrm{O}_{9}$ and (d) $\mathrm{SrK}_{2} \mathrm{P}_{4} \mathrm{O}_{12}+$

$$
\gamma\left[\mathrm{Sr}\left(\mathrm{PO}_{3}\right)_{2}\right][23,42]
$$

Table 6: Frequencies $\left(\mathrm{cm}^{-1}\right)$ of IR absorption bands for $\mathrm{SrKP}_{3} \mathrm{O}_{9} \cdot 3 \mathrm{H}_{2} \mathrm{O}$

\begin{tabular}{|c|c|}
\hline Frequencies $\left(\mathrm{cm}^{-1}\right)$ & Vibrations \\
\hline 3416 & $v$ OH \\
\hline 1616 & $\delta$ HOH \\
\hline 1307 & $v_{\text {as }}$ OPO \\
1271 & \\
\hline 1159 & $v_{\mathrm{s}} \mathrm{OPO}$ \\
1120 & \\
1103 & $v_{\text {as }}$ POP \\
\hline 983 & \\
\hline 871 & $v_{\mathrm{s}} \mathrm{POP}$ \\
\hline 744 & \\
\hline 688 & $\delta$ OPO \\
\hline 645 & + \\
635 & $\rho \mathrm{OPO}$ \\
\hline 526 & \\
\hline
\end{tabular}

The IR absorption spectra of $\mathrm{SrKP}_{3} \mathrm{O}_{9} \cdot 3 \mathrm{H}_{2} \mathrm{O}$ and $\mathrm{SrKP}_{3} \mathrm{O}_{9}$ are reported in Fig.3. In the domain 4000-1600 $\mathrm{cm}^{-1}$, the spectrum (a) (Fig. 3a) shows three bands at 3568, 2400 and $1611 \mathrm{~cm}^{-1}$. The band at $3568 \mathrm{~cm}^{-1}$ is attributed to the stretching vibrations of water molecules $(\mathrm{vO}-\mathrm{H})$.

The band at $2400 \mathrm{~cm}^{-1}$ corresponds to hydrogen bonding [23].

The band at $1611 \mathrm{~cm}^{-1}$ represents the bending vibration of water molecules $(\delta \mathrm{HOH})$. The domain $1400-650 \mathrm{~cm}^{-1}$, characteristic of the valence vibration bands of the cycle.Among these bands can be distinguished:

- The vibration bands of the (OPO) end groups at high frequencies: $1180<v_{\text {as }}$ OPO $<1340 \mathrm{~cm}^{-1}$ and $1060<v_{\mathrm{s}}$ OPO $<1180 \mathrm{~cm}^{-1}$;

- the valency vibrations of the (P-O-P) ring groups at : 960 $<v_{\mathrm{as}} \mathrm{POP}<1060 \mathrm{~cm}^{-1}$ and

$660<v_{\mathrm{s}}$ POP $<960 \mathrm{~cm}^{-1}$;

3.4 $\mathrm{P}_{4} \mathrm{O}_{12}{ }^{4-}$

\section{$\mathrm{SrNa}_{2} \mathrm{P}_{4} \mathrm{O}_{12} \cdot 6 \mathrm{H}_{2} \mathrm{O}$}

Polycrystalline samples of $\mathrm{SrNa}_{2} \mathrm{P}_{4} \mathrm{O}_{12} \cdot 6 \mathrm{H}_{2} \mathrm{O}$ were readily prepared by mixing concentrated solutions of
$\mathrm{Na}_{2} \mathrm{P}_{4} \mathrm{O}_{12} \cdot 4 \mathrm{H}_{2} \mathrm{O}$ and $\mathrm{Sr}\left(\mathrm{NO}_{3}\right)_{2}$ in an equimolar ratio and allowing the mixture to evaporate at room temperature for a few days[31] [32].

\section{$\mathrm{SrK}_{2} \mathrm{P}_{4} \mathbf{O}_{12}$}

$\mathrm{SrKP}_{3} \mathrm{O}_{9}$ leads between 400 and $650{ }^{\circ} \mathrm{C}$, to a mixture of $\mathrm{SrK}_{2} \mathrm{P}_{4} \mathrm{O}_{12}$ crystallized and $\beta\left[\mathrm{Sr}\left(\mathrm{PO}_{3}\right)_{2}\right]$ amorphousphase in $\mathrm{X}$-ray diffraction. This mixture is stable until the melting points at $696{ }^{\circ} \mathrm{C}$ of $\mathrm{SrK}_{2} \mathrm{P}_{4} \mathrm{O}_{12}$ see above the figure. 3 [23].

\section{$\operatorname{Sr}\left(\mathrm{NH}_{4}\right)_{2} \mathbf{P}_{4} \mathbf{O}_{12}$,}

$\mathrm{Sr}\left(\mathrm{NH}_{4}\right)_{2} \mathrm{P}_{4} \mathrm{O}_{12}, \mathrm{SrTl}_{2} \mathrm{P}_{4} \mathrm{O}_{12}$, and $\mathrm{SrRb}_{2} \mathrm{P}_{4} \mathrm{O}_{12}$. These three salts isotypic with $\mathrm{SrK}_{2} \mathrm{P}_{4} \mathrm{O}_{12}$.

Fiften mmol $(4,82 \mathrm{~g})$ of anhydrous $\left(\mathrm{NH}_{4}\right)_{4} \mathrm{P}_{4} \mathrm{O}_{12}$, obtained from $\mathrm{Na}_{4} \mathrm{P}_{4} \mathrm{O}_{12} .4 \mathrm{H}_{2} \mathrm{O}$, were dissolved in $60 \mathrm{~cm}^{3}$ of water.fiften- $\mathrm{cm}^{3}(7,5 \mathrm{mmol})$ of the $0.5 \mathrm{~mol} \mathrm{dm}{ }^{-3}$ strontium stirred.After $1 \mathrm{~h}$,the precipitate was filtered off and dried as described above. At least $92 \%$ of the $\mathrm{P}$ atoms were in the form of cyclo-tetraphosphate. [33]

\section{$\mathrm{Cs}_{4} \mathrm{Sr}_{3} \mathrm{H}_{2}\left(\mathrm{P}_{4} \mathrm{O}_{12}\right)_{3}$}

During experiments to optimize the chemical preparations of the tetrametaphosphate-polyphosphate of Cs-Sr, $\mathrm{Sr}_{2} \mathrm{Cs}_{3}\left(\mathrm{P}_{4} \mathrm{O}_{12}\right)\left(\mathrm{PO}_{3}\right)_{3}$, and of the Cs- $\mathrm{Pb}$ polyphosphate $\mathrm{PbCs}_{2}\left(\mathrm{PO}_{3}\right)_{4}$ frequently observed the formation of tetrahedra slightly soluble in water. This solubility proves that the compound is not a polyphosphate but probably a Cs-rich cyclophosphate. The structural analysis shows that this salt is $\mathrm{Cs}_{4} \mathrm{Sr}_{3} \mathrm{H}_{2}\left(\mathrm{P}_{4} \mathrm{O}_{12}\right)_{3} \cdot[34]$

\section{$\mathrm{Sr}\left[\mathrm{NH}_{3}\left(\mathrm{CH}_{2}\right)_{2} \mathrm{NH}_{3}\right] \mathbf{P}_{4} \mathrm{O}_{12} .5 \mathrm{H}_{2} \mathrm{O}$}

The process for the preparation of the title compound is identical to that used for all the salts of the series. Crystals were prepared by adding strontium carbonate and ethylenediamine in a stoichiometric ratio to a water solution of cyclo-tetraphosphoric acid kept at low temperature ( $\mathrm{T}<$ $278 \mathrm{~K}$ ); after slow evaporation large prisms with rectangular section are obtained [35]

\section{* Crystallographic data}

Table 7: Main Crystallographic Data for the cyclotetraphosphates associated to strontium

\begin{tabular}{|c|c|c|c|c|c|}
\hline Formula & $\begin{array}{c}\mathrm{a}(\AA) \\
\alpha^{\circ}\end{array}$ & $\begin{array}{c}\mathrm{b}(\AA) \\
\beta^{\circ}\end{array}$ & $\begin{array}{c}\mathrm{c}(\AA) \\
\gamma^{\circ}\end{array}$ & $\begin{array}{c}\text { Space } \\
\text { Group }\end{array}$ & $\mathrm{Z}$ \\
\hline $\mathrm{SrNa}_{2} \mathrm{P}_{4} \mathrm{O}_{12} \cdot 6 \mathrm{H}_{2} \mathrm{O}$ & 9.838 & 9.838 & 5.003 & $P 4 / n b m$ & 2 \\
\hline $\mathrm{SrK}_{2} \mathrm{P}_{4} \mathrm{O}_{12}$ & 7.445 & 7.445 & 10.17 & $\mathrm{I}-4$ & 2 \\
\hline $\mathrm{Sr}\left(\mathrm{NH}_{4}\right)_{2} \mathrm{P}_{4} \mathrm{O}_{12}$ & 7.575 & 7.575 & 10.26 & $\mathrm{I}-4$ & \\
\hline $\mathrm{SrTl}_{2} \mathrm{P}_{4} \mathrm{O}_{12}$ & 7.608 & 7.608 & 10.25 & $\mathrm{I}-4$ & 2 \\
\hline $\mathrm{SrRb}_{2} \mathrm{P}_{4} \mathrm{O}_{12}$ & 7.585 & 7.585 & 10.28 & $\mathrm{I}-4$ & 2 \\
\hline $\mathrm{Cs}_{4} \mathrm{Sr}_{3} \mathrm{H}_{2}\left(\mathrm{P}_{4} \mathrm{O}_{12}\right)_{3}$ & 14.544 & 15.455 & 15.455 & $\mathrm{I}-43 \mathrm{~d}$ & 2 \\
\hline $\mathrm{Sr}\left[\mathrm{NH}_{3}\left(\mathrm{CH}_{2}\right)_{2} \mathrm{NH}_{3}\right] \mathrm{P}_{4} \mathrm{O}_{12} .5 \mathrm{H}_{2} \mathrm{O}$ & 17.863 & 15.317 & 13.109 & Pbca & 8 \\
\hline
\end{tabular}


Rachida Oubouaza et al., International Journal of Emerging Trends in Engineering Research, 8(9), September 2020, 6587 - 6598

\section{5 $\mathrm{P}_{6} \mathrm{O}_{18}{ }^{6-}$}

\section{$\mathrm{Sr}_{2}\left(\mathrm{NH}_{4}\right)_{2} \mathbf{P}_{6} \mathbf{O}_{18} \cdot 7 \mathrm{H}_{2} \mathrm{O}$}

Ammonium strontium cyclo-hexaphosphatehepta hydrate $\mathrm{Sr}_{2}\left(\mathrm{NH}_{4}\right)_{2} \mathrm{P}_{6} \mathrm{O}_{18} .7 \mathrm{H}_{2} \mathrm{O}$,five mmol (3.045g) of $\left(\mathrm{NH}_{4}\right)_{2} \mathrm{P}_{6} \mathrm{O}_{18} .1,5 \mathrm{H}_{2} \mathrm{O}$ were dissolved in $30 \mathrm{~cm}^{3}$ of water. Then the solution was mixed with $20 \mathrm{~cm}^{3}(10 \mathrm{mmol})$ of the $0.5 \mathrm{~mol}$ $\mathrm{dm}^{-3}$ strontium chloride solution. The mixture was stirred for $30 \mathrm{~min}$.the precipitate was then filtered off, washed, and dried as above found $\mathrm{Sr}, 21.87 ; \mathrm{N}, 3.32 ; \mathrm{P}, 23.03 ; \mathrm{H}_{2} \mathrm{O}, 15.57 \%$.Calcd for

$\mathrm{Sr}_{2}\left(\mathrm{NH}_{4}\right)_{2} \mathrm{P}_{6} \mathrm{O}_{18} .7 \mathrm{H}_{2} \mathrm{O}: \mathrm{Sr}, 21.61 ; \mathrm{N}, 3.45 ; \mathrm{P}, 22.91 ; \mathrm{H}_{2} \mathrm{O}, 15.53 \%$. At least $97 \%$ of the $\mathrm{P}$ atoms were found as cyclo- $\mathrm{P}_{6} \mathrm{O}_{18}{ }^{6-}$ ions [33].

\subsection{Long chain polyphosphates $\left(\mathrm{PO}_{3}{ }^{-}\right)_{\mathrm{n}}$}

\section{$\mathrm{Sr}\left(\mathrm{PO}_{3}\right)_{2} \beta$ and $\gamma$ forms}

Single crystals of $\beta-\mathrm{Sr}\left(\mathrm{PO}_{3}\right)_{2}$ and $\gamma-\mathrm{Sr}\left(\mathrm{PO}_{3}\right)_{2}$ were obtained from mixtures of $\mathrm{NH}_{4} \mathrm{H}_{2} \mathrm{PO}_{4}, \mathrm{SrCl}_{2}$ and $\mathrm{Y}_{2} \mathrm{O}_{3}$ taken respectively in molar ratios $\mathrm{Y}: \mathrm{Sr}: \mathrm{P}=1: 20: 150$ and $\mathrm{Y}: \mathrm{Sr}$ : $\mathrm{P}=2: 40: 100$ and brought respectively to $623 \mathrm{~K}$ and $773 \mathrm{~K}$ for $16 \mathrm{~h}$, then cooled slowly $(0.2 \mathrm{~K}$ $\left.\min ^{-1}\right)[36]$.

\section{$\mathrm{Sr}\left(\mathrm{HOOCC}_{6} \mathrm{H}_{4} \mathrm{PO}_{3} \mathrm{H}\right)_{2}$, $\alpha$-phase}

To $60 \mathrm{~mL}$ of a mixture of water and ethanol $(1 / 1 \mathrm{v} / \mathrm{v})$ was $\begin{array}{lllll}\text { added } & 0.44 & \mathrm{~g} & \left(2 \times 10^{-3} \mathrm{~mol}\right) & \text { of }\end{array}$ 4-carboxyphenylphosphonicacid monohydrate, $\mathrm{HOOCC}_{6} \mathrm{H}_{4} \mathrm{PO}_{3} \mathrm{H}_{2} \cdot \mathrm{H}_{2} \mathrm{O}$. The mixture was heated under stirring until the acid dissolved. To this solution, cooled to room temperature, $0.42 \mathrm{~g}$ of $\mathrm{Sr}\left(\mathrm{NO}_{3}\right)_{2}\left(2 \times 10^{-3} \mathrm{~mol}\right)$ dissolved in $10 \mathrm{~mL}$ of water was added. Immediately after mixing a precipitate was formed. The reaction mixture was stirred for additional $10 \mathrm{~min}$. The product was obtained in a $63 \%$ yield $(0.308 \mathrm{~g})$. Elemental analysis (\%) for $\mathrm{C}_{14} \mathrm{H}_{12} \mathrm{O}_{10} \mathrm{P}_{2} \mathrm{Sr}(489.8)$ : calculated C 34.30, H2.45; found C 34.82, H 2.28 [37].

\section{$\mathrm{Sr}_{3}\left(\mathrm{OOCC}_{6} \mathrm{H}_{4} \mathrm{PO}_{3}\right)_{2.5 \cdot 7 \mathrm{H}_{2} \mathrm{O}}$}

Using an automated burette, $65.9 \mathrm{~mL}$ of $0.315 \mathrm{MNH}_{4} \mathrm{OH}$ solution was added to $1.32 \mathrm{~g}\left(6 \times 10^{-3} \mathrm{~mol}\right)$ of $4-$ carboxyphenylphosphonic acid monohydrate in $20 \mathrm{~mL}$ of water and $20 \mathrm{~mL}$ of ethanol to adjust $\mathrm{pH}$ to 9 . To this solution, $1.902 \mathrm{~g}$ of $\mathrm{Sr}\left(\mathrm{NO}_{3}\right)_{2}\left(9^{\times} 10^{-3} \mathrm{~mol}\right)$ in $20 \mathrm{~mL}$ of water was added. Slowly formed precipitate was dried over $\mathrm{P}_{2} \mathrm{O}_{5}$ in a dessicator. The yield of the product was $1.47 \mathrm{~g}(67 \%)$. Elemental analysis calculated (\%) for $\mathrm{C}_{14} \mathrm{H}_{19.4} \mathrm{O}_{15.7} \mathrm{P}_{2} \mathrm{Sr}_{3}$ (763.6): C 22.00, H 2.54; found C 21.27, H 2.54 .[37]

\section{$\mathrm{Sr}_{3}\left(\mathrm{OOCC}_{6} \mathrm{H}_{4} \mathrm{PO}_{3}\right)_{2} \cdot \mathbf{4} \mathrm{H}_{2} \mathrm{O}$}

About $0.1386 \mathrm{~g}$ of $\mathrm{Sr}_{3}\left(\mathrm{OOCC}_{6} \mathrm{H}_{4} \mathrm{PO}_{3}\right)_{2.5} .7 \mathrm{H}_{2} \mathrm{O}\left(1.8 \times 10^{-4} \mathrm{~mol}\right)$ prepared according to the above given procedure was dissolved in $8 \mathrm{~mL}$ of water. The reaction mixture was heated under auto-geneous pressure at $180^{\circ} \mathrm{C}$ for $48 \mathrm{~h}$. The yield was $0.076 \mathrm{~g} \mathrm{(57 \% ).} \mathrm{The} \mathrm{same} \mathrm{compound,} \mathrm{but} \mathrm{in} \mathrm{a} \mathrm{distinctly}$ lower yield, can be obtained by heating an aqueous solution of the starting compound until precipitation. Elemental analysis calculated (\%) for $\mathrm{C}_{14} \mathrm{H}_{16} \mathrm{O}_{14} \mathrm{P}_{2} \mathrm{Sr}_{3}$ (733.1): C 22.92,H 2.18; found C 21.12, H 1.95.[37]

\section{$\operatorname{Sr}\left(\mathrm{PO}_{3}\right)_{2}$}

Thilo and Grunze also investigated the thermal condensation of $\mathrm{Sr}\left(\mathrm{H}_{2} \mathrm{PO}_{4}\right)_{2}$ and found its course very similar to that observed in the case of calcium. $\operatorname{Sr}\left(\mathrm{PO}_{3}\right)_{2}$ produced by calcination of $\mathrm{Sr}_{3}\left(\mathrm{P}_{3} \mathrm{O}_{9}\right)_{2} \cdot 7 \mathrm{H}_{2} \mathrm{O}$ at temperatures higher than $873 \mathrm{~K}$ was identified as the $\beta$ form, isotypic with calcium and lead polyphosphates. [28]

\section{$\mathrm{SrNa}\left(\mathrm{PO}_{3}\right)_{3}$}

$\mathrm{SrNa}\left(\mathrm{PO}_{3}\right)_{3}$ appears as an incongruent melting compound decomposing at $1023 \mathrm{~K}$ in the $\mathrm{NaPO}_{3}-\mathrm{Sr}\left(\mathrm{PO}_{3}\right)_{2}$, phaseequilibrium diagram elaborated. The crystal data reported by these authors showed this salt to be isotypic with $\mathrm{PbLi}\left(\mathrm{PO}_{3}\right)_{3} \cdot[38]$

\section{$\operatorname{SrLi}\left(\mathrm{PO}_{3}\right)_{3}$}

Samples for powder studies were prepared by calcining at $700^{\circ} \mathrm{C}$ a mixture of suitable proportions of lithium carbonate, strontium carbonate and biamonic phosphate.the single crystals are prepared by calcining for $24 \mathrm{~h}_{3} \mathrm{PO}_{4}(85 \%)$ in which $2 \mathrm{~g}$ of strontium carbonate and $2 \mathrm{~g}$ of lithium carbonate have been introduced. The crystals obtained are in the form of very short oblic prisms with a square base or square platelets [39].

\section{$\mathrm{SrNa}\left(\mathrm{PO}_{3}\right)_{3}$}

Monocrystals of the compound are easily prepared by attacking a stoichiometric mixture of carbonates with an excess of orthophosphoric acid and calcining the liquor obtained between 300 and $400^{\circ} \mathrm{C}$ for 24 hours. Polycrystalline samples can be prepared by calcining a stoichiometric mixture of carbonates and diammonium monophosphate at $650^{\circ} \mathrm{C}$ for strontium salt [40].

\section{* Crystallographic data}

Table 8: Main Crystallographic Data for the polyphosphates associated to strontium

\begin{tabular}{|c|c|c|c|c|c|}
\hline Formula & $\begin{array}{c}\mathrm{a}(\AA \stackrel{\AA}{ }) \\
\alpha^{\circ}\end{array}$ & $\begin{array}{c}\mathrm{b}(\AA) \\
\beta^{\circ}\end{array}$ & $\begin{array}{c}\mathrm{c}(\AA) \\
\left.\gamma^{\circ}\right)\end{array}$ & $\begin{array}{l}\text { Space } \\
\text { Group }\end{array}$ & $\mathrm{Z}$ \\
\hline$\beta-\operatorname{Sr}\left(\mathrm{PO}_{3}\right)_{2}$ & 7,209 & $\begin{array}{c}7,9527 \\
90,64\end{array}$ & 17,414 & $\mathrm{P} 2{ }_{1} / \mathrm{c}$ & 8 \\
\hline$\gamma-\operatorname{Sr}\left(\mathrm{PO}_{3}\right)_{2}$ & 4,498 & $\begin{array}{c}10,911 \\
91.56\end{array}$ & 10,375 & $\mathrm{P} 2_{1} / \mathrm{c}$ & 4 \\
\hline $\mathrm{SrLi}\left(\mathrm{PO}_{3}\right)_{3}$ & $\begin{array}{c}7.163 \\
100.07 \\
\end{array}$ & $\begin{array}{l}7.360 \\
98.49 \\
\end{array}$ & $\begin{array}{l}6.767 \\
83.59 \\
\end{array}$ & P-1 & 8 \\
\hline $\mathrm{Sr}\left(\mathrm{PO}_{3}\right)_{2}$ & 7.204 & 7.936 & 17.40 & $P 2_{1} / c$ & 4 \\
\hline $\mathrm{SrNa}\left(\mathrm{PO}_{3}\right)_{3}$ & $\begin{array}{l}7.162 \\
99.68\end{array}$ & $\begin{array}{c}7.73 \\
97.29\end{array}$ & $\begin{array}{l}6.831 \\
83.84\end{array}$ & P-1 & 2 \\
\hline $\mathrm{Sr}\left(\mathrm{HOOCC}_{6} \mathrm{H}_{4} \mathrm{PO}_{3} \mathrm{H}\right)_{2}, \alpha$-phase & 38.736 & $\begin{array}{l}5.834 \\
95.94\end{array}$ & 7.808 & $\mathrm{P} 2{ }_{1} / \mathrm{a}$ & 4 \\
\hline $\mathrm{Sr}_{3}\left(\mathrm{OOCC}_{6} \mathrm{H}_{4} \mathrm{PO}_{3}\right)_{2} .5,7 \mathrm{H}_{2} \mathrm{O}$ & 21.59 & $\begin{array}{c}3.294 \\
114.40\end{array}$ & 12.34 & $\mathrm{P} 2_{1} / \mathrm{m}$ & 4 \\
\hline $\mathrm{Sr}_{3}\left(\mathrm{OOCC}_{6} \mathrm{H}_{4} \mathrm{PO}_{3}\right)_{2} .4 \mathrm{H}_{2} \mathrm{O}$ & 13.640 & $\begin{array}{l}5.864 \\
99.02\end{array}$ & 13.466 & $\mathrm{P} 2_{1} / \mathrm{n}$ & 4 \\
\hline $\mathrm{Sr}\left(\mathrm{HOOCC}_{6} \mathrm{H}_{4} \mathrm{PO}_{3}\right) \cdot \mathrm{H}_{2} \mathrm{O}$ & 24.480 & 8.166 & 5.689 & $\mathrm{P} 2{ }_{1} / \mathrm{c}$ & 4 \\
\hline
\end{tabular}




\begin{tabular}{|c|c|c|c|c|c|}
\hline & & 125.670 & & & \\
\hline Sr( $\left(\mathrm{HOOCC}_{6} \mathrm{H}_{4} \mathrm{PO}_{3} \mathrm{H}\right)_{2}, \beta$-phase & 46.58 & 7.868 & 5.603 & $\mathrm{P} 2{ }_{1} / \mathrm{c}$ & 4 \\
& & 123.30 & & & \\
\hline SrHOOCC $_{6} \mathrm{H}_{4} \mathrm{PO}_{3}$ & 19.902 & 5.629 & 7.743 & $\mathrm{C} 2 / \mathrm{c}$ & 4 \\
& & 96.090 & & & \\
\hline
\end{tabular}

\section{* Characterization of $\mathrm{PO}_{3}{ }^{-}$in $\alpha-\mathrm{Sr}\left(\mathrm{PO}_{3}\right)_{2}$ by IR vibration} spectrometry

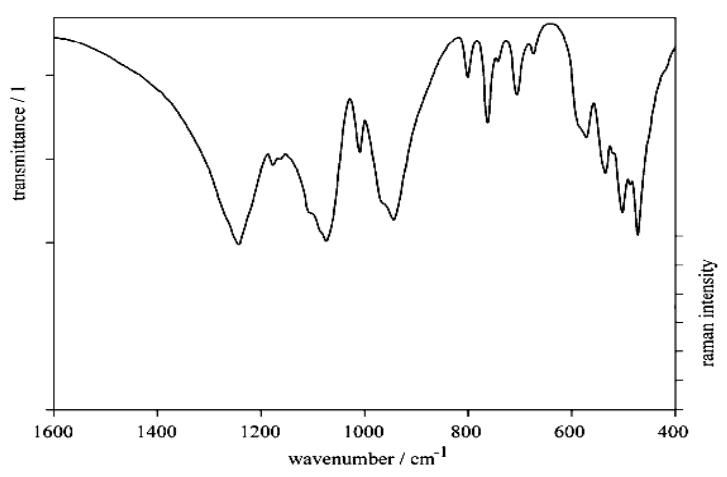

Figure 4: Infrared vibrational spectrum of $\alpha-\operatorname{Sr}\left(\mathrm{PO}_{3}\right)_{2}$.

Table 9: Frequencies $\left(\mathrm{cm}^{-1}\right)$ of IR absorption bands for $\alpha-$

\begin{tabular}{|c|c|}
\hline Fréquences $\left(\mathrm{cm}^{-1}\right)$ & Vibrations \\
\hline 1310 & $v_{\mathrm{as}} \mathrm{OPO}^{-}$ \\
\hline 1243 & $v_{\mathrm{s}} \mathrm{OPO}^{-}$ \\
\hline 1074 & $v_{\mathrm{as}} \mathrm{POP}$ \\
\hline 944 & \\
792 & $v_{\mathrm{s}} \mathrm{POP}$ \\
746 & \\
\hline 705 & $\delta \mathrm{OPO}^{-}+\rho \mathrm{OPO}^{-}$ \\
\hline 611 & \\
\hline 520 & \\
\hline
\end{tabular}

Fig.4. shows the IR spectrum of the title compound $\alpha-$ $\mathrm{Sr}\left(\mathrm{PO}_{3}\right)_{2}$. The IR spectrum of catena-polyphosphates are not significantly different from those of catena-oligophosphates. The only characteristic bands should be found in the region between 800 and 650 $\mathrm{cm}^{-1}$, where the number of bands should correspond to the periodicity of the phosphate chain. Unfortunately, this holds quite reliably only for low chain periodicities. $\operatorname{In} \alpha-\operatorname{Sr}\left(\mathrm{PO}_{3}\right)_{2}$, the characteristic frequencies of catena-polyphosphate chains such as the $v_{\text {as }}\left(\mathrm{PO}_{2}\right)$ are detected between 1200 and $1310 \mathrm{~cm}^{-1}$ with a maximum at $1243 \mathrm{~cm}^{-1}$, the very intense $v_{\mathrm{as}}(\mathrm{POP})$ at $944 \mathrm{~cm}^{-1}$ and $v\left(\mathrm{PO}_{\text {term }}\right)$ ranging from 1019 up to $1100 \mathrm{~cm}^{-1}$. Thus the observed vibrational data are in good agreement with the expected values [41].

$$
1
$$

\section{CONCLUSION}

In this work we have tried to review the different methods of preparation for condensed phosphates and monophosphates (classical methods, ion-exchange resins, Boulle's process, flux methods, thermal methods as dehydration and hydrothermal method). Furthermore, we have collected crystallographic data for the various condensed phosphates and monophosphates associated to strontium with known structures. Especially there anions, were characterized by infrared vibration spectrometry. Until today there are no condensed phosphates studied with the following anions: cyclophosphates $\mathrm{P}_{\mathrm{n}} \mathrm{O}_{3 \mathrm{n}}{ }^{\mathrm{n}-}$ ( 3 types of anions: $\mathrm{P}_{5} \mathrm{O}_{15}{ }^{5-}, \mathrm{P}_{8} \mathrm{O}_{24}{ }^{8-}$, $\left.\mathrm{P}_{12} \mathrm{O}_{36}{ }^{12-}\right)$ and oligophosphates $\left(\mathrm{P}_{\mathrm{n}} \mathrm{O}_{3 \mathrm{n}+1}\right)^{(\mathrm{n}+2)-}$ (2 types of anions : $\left.\mathrm{P}_{4} \mathrm{O}_{13}{ }^{6-}, \mathrm{P}_{5} \mathrm{O}_{16}{ }^{7-}\right)$.

\section{REFERENCES}

[1] Durif, André. Crystal chemistry of condens phosphates.Springer Science \& Business Media, 2013.

[2] Boudjada.A, Masse.R, and Guitel.J. C. Structure cristalline de l'orthophosphate monoacide de strontium: $\mathrm{SrHPO}_{4} \alpha$ : forme triclinique. Acta Crystallographica Section B: Structural Crystallography and Crystal Chemistry, 1978, 34, 9, 2692-2695. DOI :https://doi.org/10.1107/S0567740878009036

[3] Weiwei.C, Zhenzhen.L,Ruiqin.T, Shihui.T, Wei.X, Weijie.S, Junhua.Z.Comparativestudy on $\mathrm{Pb}^{2+}$ removalusing hydrothermal synthesized $\beta-\mathrm{SrHPO}_{4}$, $\mathrm{Sr}_{3}\left(\mathrm{PO}_{4}\right)_{2}$, and $\mathrm{Sr}_{5}\left(\mathrm{PO}_{4}\right)_{3}(\mathrm{OH})$ powders. Powder Technology, 2018, 329,420-425. DOI:https:// /pii/S003259101830086X

[4] Taher.L, Smiri.L, Laligant.Y and Vincent.M. Investigation of the alkaline earth phosphates: synthesis and crystal structure of a new strontium hydrogen phosphate form. Journal of Solid State Chemistry, 2000,152, 2, 428-434.

DOI: $10.1006 /$ jssc. 2000.8700

[5] Belik.A.A,Malakho.A.P, and Lazoryak.B.I. Synthesis and $\mathrm{X}$-ray Powder Diffraction Study of New Phosphates in the $\mathrm{Cu}_{3}\left(\mathrm{PO}_{4}\right)_{2}-\mathrm{Sr}_{3}\left(\mathrm{PO}_{4}\right)_{2}$ System: $\mathrm{Sr}_{1.9} \mathrm{Cu}_{4.1}\left(\mathrm{PO}_{4}\right)_{4}$, $\mathrm{Sr}_{3} \mathrm{Cu}_{3}\left(\mathrm{PO}_{4}\right)_{4}, \mathrm{Sr}_{2} \mathrm{Cu}\left(\mathrm{PO}_{4}\right)_{2}$, and $\mathrm{Sr}_{9.1} \mathrm{Cu}_{1.4}\left(\mathrm{PO}_{4}\right)$. Journal of Solid State Chemistry, 2002, 163, 1,121-131. DOI:doi.org/10.1006/jssc.2001.9380

[6] Alexei A.B, Masaki.A,Akira.M,Myung-Hwan.W, Hyun Joo.K,Jun.K,Tomoyuki.K,Susumu.O,

Hitoshi.O,Koichi.K,andMikio.T.Investigation of the crystal structure and the structural and magnetic properties of $\mathrm{SrCu}_{2}\left(\mathrm{PO}_{4}\right)_{2}$. Inorganic chemistry, 2005, 44, $19,6632-6640$.

DOI:Doi :org/10.1021/ic051079h

[7] Zhi-wei.Z, Ai-jun.S, Shi-tao.S, Jian-ping.Z, Weiguo.Z, and Dong-jun.Synthesis and luminescence properties of novel $\mathrm{KSrPO}_{4}$ : $\mathrm{Dy}^{3+}$ phosphor. Journal of Alloys and Compounds, 2015,629,32-35.

DOI :org/10.1016/j.jallcom.2014.12.066

[8] Hidouri.M,LuisaLópez.M, Pico.P,Wattiaux.A,andBen Amara.M.Synthesis and characterization of a new iron phosphate $\mathrm{KSrFe}_{2}\left(\mathrm{PO}_{4}\right)_{3}$ with a langbeinite type 
Rachida Oubouaza et al., International Journal of Emerging Trends in Engineering Research, 8(9), September 2020, 6587 - 6598

structure. Journal of Molecular Structure, 2012,1030,145148. DOI :doi.org/10.1016/j.molstruc.2012.04.002

[9] Elbali.B,Boukhari.Ali,Holt.E.M.,and J.Aride. Strontium dicobalt orthophosphate. Journal of crystallographic and spectroscopic research, 1993, 23,12, 1001-1004.

DOI :10.1007/BF01185551

[10] Yang.M, Zhang.S, Guo.W, and Zhangzhen.H. Hydrothermal synthesis and magnetic properties of a New phase of $\mathrm{SrCo}_{2}\left(\mathrm{PO}_{4}\right)_{2}$. Solid State Sciences, 2016,52,7277.

DOI:doi.org/10.1016/j.solidstatesciences.2015.12.013

[11] Pavel E. K, AndreyS.K,Martin.J, Jürgen.N, and YuryD.T.Crystal structure and properties of strontium phosphate apatite with oxocuprate ions in hexagonal channels. Zeitschriftfüranorganischeund allgemeine Chemie, 2003, 629, 2,344-352.

DOI: https://doi.org/10.1002/zaac.200390055

[12] Maass.K and Glaum.R. Strontium chromium (II) diphosphate, $\mathrm{SrCrP}_{2} \mathrm{O}_{7}$. Acta Crystallographica Section C: Crystal Structure Communications, 2000,56,4,404406.DOI: $10.1107 /$ S0108270100000226

[13] Grenier.J and Masse.R. Structure cristallographique de $\alpha-\mathrm{Sr}_{2} \mathrm{P}_{2} \mathrm{O}_{7}$.Bulletin de Minéralogie, 1967,90, 3,285-292. DOI :https://doi.org/10.3406/bulmi.1967.6124

[14] İlkay.L,Ozbayoglu.G, and Yilmaz.A.Synthesis, characterizations and investigation of thermoluminescence properties of strontium pyrophosphate doped with metals. Radiation Physics and Chemistry, 2014,104,55-60.

DOI :doi.org/10.1016/j.radphyschem.2014.04.028

[15] Guo.T, Wu.W, Wang.Y, andYongxiang.L.Relations on synthesis, crystal structure and microwave dielectric properties of $\mathrm{SrZnP}_{2} \mathrm{O}_{7}$ ceramics. Ceramics International, 2012, 38,S187-S190. DOI:https://doi.org/10.1016/j.ceramint.2011.04.080

[16] El-bali.B,Boukhari.A,Aride.J,and Maßß.K, Wald.D, Glaum.R, and Abraham.F.Crystal structure and colour of $\mathrm{SrNiP}_{2} \mathrm{O}_{7}$ and $\mathrm{SrNi}_{3}\left(\mathrm{P}_{2} \mathrm{O}_{7}\right)_{2}$. Solid state sciences, 2001, 3, 6, 669-676. DOI:https://doi.org/10.1016/S1293-2558(01)01176-1

[17] Le Meins.J.-M. and Courbion.G. $\mathrm{SrFeP}_{2} \mathrm{O}_{7}$, a new homologue in the $\mathrm{AMP}_{2} \mathrm{O}_{7}$ series. Acta Crystallographica Section C: Crystal Structure Communications, 1999,55, 4, 481-483..

DOI:https://doi.org/10.1107/S0108270198017375

[18] Boukhari.A, Moqine.A, and Flandrois.S. Synthesis and characterization of new copper (II) mixed diphosphates $(\mathrm{M}, \mathrm{Cu})_{2} \mathrm{P}_{2} \mathrm{O}_{7}$ with $\mathrm{M}=\mathrm{Mg}, \mathrm{Ca}, \mathrm{Sr}$, and $\mathrm{Ba}$. Journal of Solid State Chemistry, 1990, 87, 2, 251-256. DOI :https://doi.org/10.1016/0022-4596(90)90026-T

[19] Riou.D, and Raveau.B. Structure of $\mathrm{SrCoP}_{2} \mathrm{O}_{7}$. Acta Crystallographica Section C: Crystal Structure Communications, 1991, 47, 8, 1708-1709. DOI:https://doi.org/10.1107/S0108270191000884

[20] Alaoui El Belghiti.A,Boukhari.A, and Holt.E. M. Structures of $\mathrm{CdSrP}_{2} \mathrm{O}_{7}$ and $\mathrm{CdBaP}_{2} \mathrm{O}_{7}$. Acta Crystallographica Section C: Crystal Structure Communications, 1991,47, 3, 473-477.

DOI:https://doi.org/10.1107/S0108270190008575
[21] Tahiri.Aziz.A, El Bali.B,Lachkar.M,Ouarsal.R,and Zavalijb.P.SrMgP $\mathrm{P}_{7}$. Acta Crystallographica Section E: Structure Reports Online, 2002,58,1,i9-i11. DOI :https://doi.org/10.1107/S1600536801020633

[22] Gao.J,Liu.X,Song.L,Sha.X,Zhao.P and Guo.P. Synthesis and structure of a new halophosphate $\mathrm{Sr}_{3} \mathrm{P}_{3} \mathrm{O}_{10} \mathrm{Cl}$ with the flexible $\left[\mathrm{P}_{3} \mathrm{O}_{10}\right]^{5-}$ anions. Solid State Sciences, 2016, 55, 159-163.

DOI:10.1016/j.solidstatesciences.2016.03.008

[23] Belaaouad.S, Charaf.A,Elkababi.K,and Radid.M. Chemical preparation, crystallographic characterization, thermal behavior and IR studies of two new cyclotriphosphates $\mathrm{SrKP}_{3} \mathrm{O}_{9} \cdot 3 \mathrm{H}_{2} \mathrm{O}$ and $\mathrm{SrKP}_{3} \mathrm{O}_{9}$. Journal of Alloys and Compounds, 2009, 468, 1-2, 270274 DOI:https://doi.org/10.1016/j.jallcom.2007.12.100

[24] Belaaouad.S,Sbai.K, and Jouini.A. Chemical preparation, thermal behavior and crystal structure of a new cyclotriphosphate: $\mathrm{SrNH}_{4} \mathrm{P}_{3} \mathrm{O}_{9} \cdot 3 \mathrm{H}_{2} \mathrm{O}$. Solid state sciences, 2000, 2, 6, 655-661.

DOI :https://doi.org/10.1016/S1293-2558(00)01069-4

[25] Sbai.K,Belaaouad.S,Abouimrane.A,and Moutaabid.M. Chemical preparation, crystallographic characterization, thermal behavior and IR studies of a new cyclotriphosphate $\operatorname{SrTlP}_{3} \mathrm{O}_{9} \cdot 3 \mathrm{H}_{2} \mathrm{O}$. Materials research bulletin, 2002, 37, 5, p. 915-924.

DOI :https://doi.org/10.1016/S0025-5408(02)00710-9

[26] Hamza Marouani, Rachida Oubouaza, Soufiane Zerraf, Ali Ouasri, MalikaTridane And Said Belaaouad.

Chemical preparations, crystal data for monophosphates and condensed Phosphates associated to manganese and IR studies of their anions.International Journal of Emerging Trends in Engineering Research,2020,8,8, 4784-4797.DOI: $10.30534 /$ ijeter/2020/116882020

[27] Zilber.R, Tordjman.I, Durif.A,and Guitel.J. Structure cristalline du trimetaphosphate de strontiumsodium trihydrate: $\mathrm{SrNaP}_{3} \mathrm{O}_{9} \cdot 3 \mathrm{H}_{2} \mathrm{O}$. ZeitschriftfürKristallographie-CrystallineMaterials, 1974, 140, 5-6,350-359.

DOI :10.1524/zkri.1974.140.5-6.350

[28] Tace.El.M,Charaf.A,Fahim.I,Moutaabbid. M,Kheïreddine.A,Ouaalla.F.-E,Tridane.M,

Sbai.K,Radid.M,and Belaaouad.S. Chemical Preparation, Thermal Behavior, Kinetic, and IR Studies of $\mathrm{MnK}_{4}\left(\mathrm{P}_{3} \mathrm{O}_{9}\right)_{2} .2 \mathrm{H}_{2} \mathrm{O}$.Crystallographic Data of a New Cyclotriphosphate $\mathrm{MnK}_{4}\left(\mathrm{P}_{3} \mathrm{O} 9\right) 2$, and Quantum Chemical Calculations for the $\mathrm{P}_{3} \mathrm{O}_{9}{ }^{3-}$ Ion. Phosphorus, Sulfur, and Silicon and the Related Elements, 2011, 186,7, 1501-1514.

DOI: https://doi.org/10.1080/10426507.2010.520173

[29] Fahim.I,Kheireddine.A, Tridane.M,and Belaaouad.S. Chemical preparation and XRD data for a new triphosphate $\mathrm{CuNa}_{3} \mathrm{P}_{3} \mathrm{O}_{10}$ and two cyclotriphosphates $\mathrm{SrRbP}_{3} \mathrm{O}_{9} \cdot 3 \mathrm{H}_{2} \mathrm{O}$ and $\mathrm{SrRbP}_{3} \mathrm{O}_{9}$. Powder Diffraction, 2011,26, 1, 78-81.

DOI :https://doi.org/10.1154/1.3553180

[30] ElMakhloufy. S,Tridane.M, Majdi.E, Marouani.M, Zerraf.S, Belhabra.M,Cherqaoui.A and Belaaouad.S.Chemical preparation, thermal behavior and infrared studies of the new cyclotriphosphatetetrahydrate of manganese and 
distrontium, $\mathrm{MnSr}_{2}\left(\mathrm{P}_{3} \mathrm{O}_{9}\right)_{2} \cdot 4 \mathrm{H}_{2} \mathrm{O}$.Mediterranean Journal of Chemistry,2019, 9, 4, 280-289.

Available online at www.medjchem.com

[31] Santha, N. and Nayar.V. U. Vibrational spectra of $\mathrm{SrNa}_{2} \mathrm{P}_{4} \mathrm{O}_{12} \cdot 6 \mathrm{H}_{2} \mathrm{O}$ and $\mathrm{CaNa}_{2} \mathrm{P}_{4} \mathrm{O}_{12} \cdot 5.5 \mathrm{H}_{2} \mathrm{O}$. Journal of Raman spectroscopy, 1990, 21, 8, 517-519.

DOI: $10.1002 /$ jrs. 1250210808

[32] Durif.A, Averbuch-Pouchot.M. T, and Guitel.J. C. Structure of disodium strontiumTetrametaphosphate hexahydrate, $\mathrm{SrNa}_{2} \mathrm{P}_{4} \mathrm{O}_{12} \cdot 6 \mathrm{H}_{2} \mathrm{O}$. Acta Crystallographica Section C: Crystal Structure Communications, 1983, 39, 7,812-813.DOI: $10.1107 / \mathrm{s} 0108270183006447$

[33] Takenaka.A,Motooka.I, and Nariai.H. The thermal decomposition of ammonium strontium cyclo-tri-, cyclo-tetra-, and cyclo-hexaphosphate. Bulletin of the Chemical Society of Japan, 1989, 62, 9,2819-2823. DOI:https://doi.org/10.1246/bcsj.62.2819

[34] Averbuch-Pouchot.M.T, and Durif.A. $\mathrm{Cs}_{4} \mathrm{Sr}_{3} \mathrm{H}_{2}\left(\mathrm{P}_{4} \mathrm{O}_{12}\right)_{3}$, a new derivative of $\mathrm{Al}_{4}\left(\mathrm{P}_{4} \mathrm{O}_{12}\right)_{3}$. Acta Crystallographica Section C: Crystal Structure Communications, 1985,41,11, 1557-1558.

DOI: $10.1107 / \mathrm{s} 010827018500854 \mathrm{x}$

[35] Bagieu-Beucher.M,Durif.A, and Guitel.J.C. Structure of A strontium ethylenediammoniumcyclo-tetraphosphate hydrate.Acta Crystallographica Section C: Crystal Structure Communications, 1988, 44, 12, 2063-2065. DOI: $10.1107 / \mathrm{s} 0108270188008479$

[36] Graia.M, Driss.A,and Jouini.T.Polyphosphates de strontium $\quad \mathrm{Sr}\left(\mathrm{PO}_{3}\right)_{2}$ formes $\beta$ et $\gamma$. Acta Crystallographica Section C: Crystal Structure Communications, 1999, 55, 9,1395-1398.

DOI :https://doi.org/10.1107/S0108270199003637

[37] Zima.V,Svoboda.J,Benes.L,Melanova.K,Trchova.M,and Dybal.J. Synthesis and characterization of new strontium 4-carboxyphenylphosphonates. Journal of Solid State Chemistry, 2007, 180, 3,929-939.

DOI :https://doi.org/10.1016/j.jssc.2006.12.021

[38] Durif-Varambon .A,Bagieu-Beucher.M,Martin.C,and Jean claude.G. Données cristallographiques sur un trimétaphosphate de strontium hydraté: $\mathrm{Sr}_{3}\left(\mathrm{P}_{3} \mathrm{O}_{9}\right)_{2} \bullet 7 \mathrm{H}_{2} \mathrm{O}$ et sur le polyphosphate de strontium: $\mathrm{Sr}\left(\mathrm{PO}_{3}\right)_{2}$. Bulletin de Minéralogie, 1972, 95, 1,146-148. DOI: https://www.persee.fr/doc/bulmi_00379328_1972_act_95_1_6659

[39] Martin.C and Durif-Varambon.A. Données cristallographiques sur le trimétaphosphate de lithiumstrontium: $\mathrm{LiSr}\left(\mathrm{PO}_{3}\right)_{3}$. Détermination du diagramme d'équilibre $\mathrm{LiPO}_{3}-\mathrm{Sr}\left(\mathrm{PO}_{3}\right)_{2}$. Bulletin de Minéralogie, 1969,92, 5,489-490.

DOI :https://doi.org/10.3406/bulmi.1969.6402

[40] Martin.C and Durif-Varambon.A. Étude des systèmes $\mathrm{NaPO}^{3-} \mathrm{Ba} \quad\left(\mathrm{PO}_{3}\right)_{2}$ et $\mathrm{NaPO}^{3-} \mathrm{Sr}\left(\mathrm{PO}_{3}\right)_{2}$. Données cristallographiques sur $\mathrm{NaBa}\left(\mathrm{PO}_{3}\right)_{3}, \quad \mathrm{SrNa} \quad\left(\mathrm{PO}_{3}\right)_{3}$, $\mathrm{BaNa}\left(\mathrm{PO}_{3}\right)_{3} \bullet 4 \mathrm{H}_{2} \mathrm{O}$ et $\mathrm{SrNa}\left(\mathrm{PO}_{3}\right)_{3} \bullet 3 \mathrm{H}_{2} \mathrm{O}$. Bulletin de Minéralogie, 1972,95,1,149-153.

DOI :https://doi.org/10.3406/bulmi.1972.6660

[41] Höppe.H.A.The synthesis, crystal structure and vibrational spectra of $\alpha-\operatorname{Sr}\left(\mathrm{PO}_{3}\right)_{2}$ containing an unusual catena-polyphosphate helix.Solid state sciences, 2005,7, 10,1209-1215.

DOI: 10.1016/j.solidstatesciences.2005.06.014

[42] Zerraf.S,Tridane.M, and Belaaouad. S. Data of infrared vibration spectroscopy of cyclotriphosphates.Data in brief, 2019, 25, 104075.

DOI: https://doi.org/10.1016/j.dib.2019.104075

[43] Belhabra.M,Fahim.I,Atibi.A,ElKababi.K, Ouasri.A, Zerraf.S, Tridane. M, Radid. M, and Belaaouad.S.Vibrational study and thermal behavior of dihydrogenotriphosphate trihydrate of 4-aminobenzoic acid and its anhydrous new form fertilizer type NP. Mediterranean Journal of Chemistry, 2019,8, 4, 270282.DOI:http://dx.doi.org/10.13171/mjc841905308mb

[44] Hamza Marouani,Malika Tridane,El Mehdi Majdi, Soufiane Zerraf, Mustafa Belhabra and Said Belaaouad.characterization and Thermal Behavior of two new cyclotriphosphates International Journal of Emerging Trends in Engineering Research , 2020,8, 1. DOI :https://doi.org/10.30534/ijeter/2020/30812020 